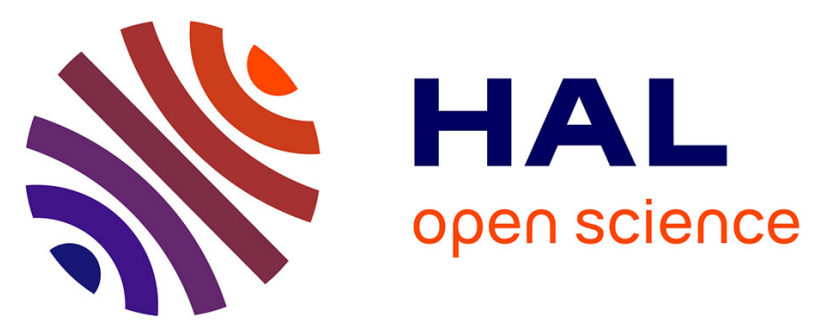

\title{
Uniform nanosized oxide particles dispersion strengthened tungsten alloy fabricated involving hydrothermal method and hot isostatic pressing
}

Fangnao Xiao, Qiang Miao, Shizhong Wei, Thierry Barriere, Gang Cheng, Shiwei Zuo, Liujie Xu

\section{To cite this version:}

Fangnao Xiao, Qiang Miao, Shizhong Wei, Thierry Barriere, Gang Cheng, et al.. Uniform nanosized oxide particles dispersion strengthened tungsten alloy fabricated involving hydrothermal method and hot isostatic pressing. Journal of Alloys and Compounds, 2020, 824, pp.153894. 10.1016/j.jallcom.2020.153894 . hal-02993940

\section{HAL Id: hal-02993940 \\ https://hal.science/hal-02993940}

Submitted on 10 Nov 2020

HAL is a multi-disciplinary open access archive for the deposit and dissemination of scientific research documents, whether they are published or not. The documents may come from teaching and research institutions in France or abroad, or from public or private research centers.
L'archive ouverte pluridisciplinaire HAL, est destinée au dépôt et à la diffusion de documents scientifiques de niveau recherche, publiés ou non, émanant des établissements d'enseignement et de recherche français ou étrangers, des laboratoires publics ou privés. 
Alloys and Compounds

Elsevier Editorial System(tm) for Journal of

Manuscript Draft

Manuscript Number: JALCOM-D-19-15261R1

Title: Uniform nanosized oxide particles dispersion strengthened tungsten alloy fabricated involving hydrothermal method and hot isostatic pressing

Article Type: Full Length Article

Keywords: Oxide particle strengthening; Liquid-liquid doping; Compressive strength; Constitutive equation; ODS-W alloy.

Corresponding Author: Dr. fangnao xiao,

Corresponding Author's Institution:

First Author: fangnao xiao

Order of Authors: fangnao xiao; qiang miao; Shizhong wei; Shiwei zuo; Thierry Barriere; Gang Cheng; Liujie xu

Abstract: In this article, we reported a processing route for fabricating extremely uniform and ultrafine Zr(Y)O2 particles diffusely distributed in the tungsten matrix. More than 90\% of oxide particles are between 100 and $650 \mathrm{~nm}$ in diameter. The refinement mechanism of $\mathrm{Zr}(\mathrm{Y}) \mathrm{O} 2$ particles was discussed. Under TEM observation, lots of $\mathrm{Zr}(\mathrm{Y}) \mathrm{O} 2$ particles with a diameter of less than $50 \mathrm{~nm}$ are dispersed in tungsten matrix. HRTEM analysis reveals that the $\mathrm{Zr}(\mathrm{Y}) \mathrm{O} 2$ particles exhibit a good bonding with the tungsten phase, but without coherent relation at interface. The fabricated $\mathrm{W}$ alloy reinforced by $0.25 \mathrm{wt} \% \mathrm{Zr}(\mathrm{Y}) 02$ exhibits excellent compressive strength of $1577 \mathrm{MPa}$ and fracture strain of 0.262, higher than those of the pure $W$ and the published experimental results. The fracture surface mainly consists of transgranular fracture and involves significant $W$ grain tearing and grain deformations, confirming the strengthening effect caused by nanosized Zr(Y)O2 particles. The hot deformation behavior of $\mathrm{W}-\mathrm{Zr}(\mathrm{Y}) \mathrm{O} 2$ alloy at high temperature was investigated through establishing constitutive equation based on the Arrhenius model. 


\section{Uniform nanosized oxide particles dispersion strengthened} tungsten alloy fabricated involving hydrothermal method and

\section{hot isostatic pressing}

Fangnao Xiao ${ }^{\mathrm{a}}$, Qiang $\mathrm{Miao}^{\mathrm{a} *}$, Shizhong $\mathrm{Wei}^{\mathrm{b} *}$, Thierry Barriere ${ }^{\mathrm{d}}$, Gang Cheng ${ }^{\mathrm{e}}$, Shiwei Zuo ${ }^{\mathrm{a}}$, Liujie $\mathrm{Xu}^{\mathrm{c} *}$

${ }^{a}$ College of Material Science and Technology, Nanjing University of Aeronautics and Astronautics, 29 Yudao Street, Nanjing 210000, China

${ }^{\mathrm{b}}$ National Joint Engineering Research Center for abrasion control and molding of metal materials, Henan University of Science and Technology, Luoyang 471003, China

${ }^{\mathrm{c}}$ Henan Key Laboratory of High Temperature Structural and Functional Materials d Univ. Bourgogne Franche-Comté, FEMTO-ST Institute, CNRS/UFC/ENSMM/UTBM, Department of Applied Mechanics, 25000 Besançon, France

e INSA CVL, Univ. Tours, Univ. Orléans, LaMé, 3 rue de la Chocolaterie, BP 3410, 41034 Blois Cedex, France

*Corresponding author

Tel.:+86-379-64270020

E-mail addresses: miaoqiang@ nuaa.edu.cn (Qiang Miao)

wsz@ haust.edu.cn (Shizhong Wei)

xlj@haust.edu.cn (Liujie Xu)

\section{Abstract}

In this article, we reported a processing route for fabricating extremely uniform and ultrafine $\mathrm{Zr}(\mathrm{Y}) \mathrm{O}_{2}$ particles diffusely distributed in the tungsten matrix. More than $90 \%$ of oxide particles are between 100 and $650 \mathrm{~nm}$ in diameter. The refinement mechanism of $\mathrm{Zr}(\mathrm{Y}) \mathrm{O}_{2}$ particles was discussed. Under TEM observation, lots of $\mathrm{Zr}(\mathrm{Y}) \mathrm{O}_{2}$ particles with a diameter of less than $50 \mathrm{~nm}$ are dispersed in tungsten matrix. HRTEM analysis reveals that the $\mathrm{Zr}(\mathrm{Y}) \mathrm{O}_{2}$ particles exhibit a good bonding with the tungsten phase, but without coherent relation at interface. The fabricated $\mathrm{W}$ alloy 
reinforced by $0.25 \mathrm{wt} \% \mathrm{Zr}(\mathrm{Y}) \mathrm{O}_{2}$ exhibits excellent compressive strength of $1577 \mathrm{MPa}$ and fracture strain of 0.262 , higher than those of the pure $\mathrm{W}$ and the published experimental results. The fracture surface mainly consists of transgranular fracture and involves significant $\mathrm{W}$ grain tearing and grain deformations, confirming the strengthening effect caused by nanosized $\mathrm{Zr}(\mathrm{Y}) \mathrm{O}_{2}$ particles. The hot deformation behavior of $\mathrm{W}-\mathrm{Zr}(\mathrm{Y}) \mathrm{O}_{2}$ alloy at high temperature was investigated through establishing constitutive equation based on the Arrhenius model.

Keywords: Oxide particle strengthening; Liquid-liquid doping; Compressive strength; Constitutive equation; ODS-W alloy.

\section{Introduction}

Over the past years, oxide particle dispersed into the tungsten matrix (ODS-W), was expected to obtain excellent mechanical properties by improving densification, refining the grains, impeding dislocation motion [1-3]. As tungsten is a refractory metal, conventionally, to achieve full densification, its sintering temperature would reach to $2000-2500{ }^{\circ} \mathrm{C}$ for a long holding time [4]. However, high temperature sintering usually leads to tungsten grains growing rapidly, which causes deteriorative properties, such as high ductile-brittle transition temperature (DBTT>400 ${ }^{\circ} \mathrm{C}$ ), recrystallization brittleness and poor mechanical properties at high temperature [5-7].

However, the improvement of mechanical properties of ODS-W alloy is limited for the application at high temperature and the increase of strength is often accompanied with the decrease of ductility [8]. A significant reason is that, the coarse oxide particles are usually located at the grains boundaries of alloys and then act as stress concentration, weakening the cohesion of interface between oxide particle and matrix and then leading to intergranular fracture and low toughness [8-10]. Thus, on the premise of ensuring high density and small grain size, reducing the oxide particle size becomes one of the research topics for ODS-W alloy. It was reported that ultrafine $\mathrm{La}_{2} \mathrm{O}_{3}$ or $\mathrm{Y}_{2} \mathrm{O}_{3}$ doping tungsten powders can be prepared by wet chemical techniques $[11,12]$. However, during high temperature environment, $\mathrm{La}_{2} \mathrm{O}_{3}$ and $\mathrm{Y}_{2} \mathrm{O}_{3}$ particles in $\mathrm{W}$ matrix appear to agglomerate and then form larger particles, which 
could deteriorate the alloys' mechanical properties [13-15].

Considering the higher compatibility of ceramic oxide $\left(\mathrm{ZrO}_{2}, \mathrm{Al}_{2} \mathrm{O}_{3}\right)$ with W matrix than rare earth oxide [16], in our previous research, our group prepared $\mathrm{W}-\mathrm{ZrO}_{2}$ alloy by vertical sintering and hot swaging from ultrafine powder by the wet chemical method [17]. The average size of $\mathrm{ZrO}_{2}$ particle in tungsten matrix is about $1.5 \mu \mathrm{m}$. Wang et al. [18] prepared $\mathrm{W}-\mathrm{Al}_{2} \mathrm{O}_{3}$ alloys through the hydrothermal method, followed by the $\mathrm{H}_{2}$ reduction process and the conventional $\mathrm{H}_{2}$ sintering. However, the $\mathrm{Al}_{2} \mathrm{O}_{3}$ particles embedded in tungsten matrix still reach to $3 \mu \mathrm{m}$.

It implies that it is difficult to prepare nanosized ceramic oxide particle reinforced tungsten alloy through the liquid-liquid method. However, in view of mixing soluble raw materials in a molecular level, the liquid-liquid method is still a candidate method for preparing high quality doped powder [10]. Moreover, it is determined that mechanical milling is usually adopted to obtain nanosized powders $[19,20]$. Therefore, the combining of the above two methods was expected to obtain high-quality doped tungsten powder with ultrafine and uniform ceramic oxide particles.

In the present experiment, through hydrothermal synthesis and mechanical alloying, the doped powders with different $\mathrm{Zr}(\mathrm{Y}) \mathrm{O}_{2}$ contents were prepared. Then, hot isostatic pressing (HIP) was adopted for the fabrication of high density $\mathrm{W}-\mathrm{Zr}(\mathrm{Y}) \mathrm{O}_{2}$ alloy to reduce tungsten grains size [22-25]. Through the above processes, $\mathrm{Zr}(\mathrm{Y}) \mathrm{O}_{2}$ particle with average size of $410 \mathrm{~nm}$ are obtained in the tungsten matrix. Moreover, the effects of the $\mathrm{Zr}(\mathrm{Y}) \mathrm{O}_{2}$ content on the microstructure and properties of the $\mathrm{W}-\mathrm{Zr}(\mathrm{Y}) \mathrm{O}_{2}$ alloys were analyzed. In addition, the deformation behavior of $\mathrm{W}$ $\mathrm{Zr}(\mathrm{Y}) \mathrm{O}_{2}$ alloy was investigated by hot compression deformation at different temperatures and strain rates and then the constitutive equation was established.

\section{Experimental procedure}

\subsection{Composition and preparation processes of $\mathrm{W}-\mathrm{Zr}(\mathrm{Y}) \mathrm{O}_{2}$ alloys}

In present work, we prepared the $\mathrm{W}-\mathrm{Zr}(\mathrm{Y}) \mathrm{O}_{2}$ alloys through the hydrothermal method, followed by mechanical alloying and hot isostatic pressing. The raw materials were commercial zirconium oxychloride octahydrate $\left(\mathrm{ZrOCl}_{2} \cdot 8 \mathrm{H}_{2} \mathrm{O}\right.$; grade 
AR), yttrium nitrate $\left[\mathrm{Y}\left(\mathrm{NO}_{3}\right)_{3} \cdot 6 \mathrm{H}_{2} \mathrm{O}\right.$; grade $\left.\mathrm{AR}\right]$ and ammonium metatungstate $\left[\left(\mathrm{NH}_{4}\right)_{6} \mathrm{H}_{2} \mathrm{~W}_{12} \mathrm{O}_{40} \cdot 5 \mathrm{H}_{2} \mathrm{O}\right.$; grade AR; AMT]. The five $\mathrm{W}-\mathrm{Zr}(\mathrm{Y}) \mathrm{O}_{2}$ alloys containing $0 \%$, $0.25 \mathrm{wt} \%$, 0.5wt $\%$, 0.75wt $\%$ and $5.0 \mathrm{wt} \% \mathrm{Zr}(\mathrm{Y}) \mathrm{O}_{2}$, were denoted as $\mathrm{H}_{0}, \mathrm{H}_{0.25}, \mathrm{H}_{0.5}$, $\mathrm{H}_{0.75}$ and $\mathrm{H}_{5.0}$, respectively, as listed in Table 1 .

Table 1 Chemical composition of $\mathrm{W}-\mathrm{Zr}(\mathrm{Y}) \mathrm{O}_{2}$ alloys.

\begin{tabular}{clcc}
\hline Samples & $\mathrm{W}($ wt.\%) & $\mathrm{ZrO}_{2}($ wt.\% $)$ & $\mathrm{Y}_{2} \mathrm{O}_{3}$ (wt.\%) \\
\hline $\mathrm{H}_{0}$ & 100.000 & 0.000 & 0.000 \\
$\mathrm{H}_{0.25}$ & 99.718 & 0.250 & 0.032 \\
$\mathrm{H}_{0.50}$ & 99.437 & 0.500 & 0.063 \\
$\mathrm{H}_{0.75}$ & 99.154 & 0.750 & 0.096 \\
$\mathrm{H}_{5.0}$ & 94.370 & 5.000 & 0.630 \\
\hline
\end{tabular}

The procedures for fabricating alloy comprise the following steps: Firstly, $\mathrm{ZrOCl}_{2} \cdot 8 \mathrm{H}_{2} \mathrm{O}, \mathrm{Y}\left(\mathrm{NO}_{3}\right)_{3} \cdot 6 \mathrm{H}_{2} \mathrm{O}$ and $\left(\mathrm{NH}_{4}\right)_{6} \mathrm{H}_{2} \mathrm{~W}_{12} \mathrm{O}_{40} \cdot 5 \mathrm{H}_{2} \mathrm{O}$ were dissolved in distilled water, respectively. Subsequently, a certain amount of $\mathrm{ZrOCl}_{2} \cdot 8 \mathrm{H}_{2} \mathrm{O}$ and $\mathrm{Y}\left(\mathrm{NO}_{3}\right)_{3} \cdot 6 \mathrm{H}_{2} \mathrm{O}$ were homogeneously mixed. Then, the mixture was added slowly to the $\left(\mathrm{NH}_{4}\right)_{6} \mathrm{H}_{2} \mathrm{~W}_{12} \mathrm{O}_{40} \cdot 5 \mathrm{H}_{2} \mathrm{O}$ solution with stirring. $\mathrm{HNO}_{3}$ was adopt to decrease the solution's $\mathrm{pH}$ value to lower than 1.0. Finally, the mixed solution was put into a stainless-steel autoclave with a PTFE lining. The autoclave was sealed and then heated at $276.5 \mathrm{~K} \mathrm{~min}^{-1}$ until the reaction temperature was reached to $120{ }^{\circ} \mathrm{C}$. The holding time of the hydrothermal reaction was $17 \mathrm{~h}$. After that, the product was stirred for 120 min using an electric mixer with some distilled water. Through drying at $90{ }^{\circ} \mathrm{C}$, the precursor powder was obtained. The obtained powder was calcined at $550{ }^{\circ} \mathrm{C}$ for $4 \mathrm{~h}$ in air and then was reduced through the hydrogen reduction processes $550{ }^{\circ} \mathrm{C}(2 \mathrm{~h})+900{ }^{\circ} \mathrm{C}(2 \mathrm{~h})$, obtaining the $\mathrm{W}-\mathrm{Zr}(\mathrm{Y}) \mathrm{O}_{2}$ powders. SEM image of the reduced $\mathrm{W}-0.75 \mathrm{wt} \% \mathrm{Zr}(\mathrm{Y}) \mathrm{O}_{2}$ powder was shown in Fig. 1a.

Milling experiments of the $\mathrm{W}-\mathrm{Zr}(\mathrm{Y}) \mathrm{O}_{2}$ powders were carried out in a planetary ball with milling speed of $250 \mathrm{rpm}$. The milling media is $\mathrm{WC}$ ball consisting of $3 \mathrm{~mm}$ in diameter with ball-to-powder ratio of 10:1. The morphology of the milled $\mathrm{W}-0.75 \mathrm{wt} \% \mathrm{Zr}(\mathrm{Y}) \mathrm{O}_{2}$ powder was shown in Fig. 1b. After that, the milled powders were pressed by the cold isostatic pressing process at a pressure of $250 \mathrm{MPa}$. The 
green compacts were then sintered at $2400{ }^{\circ} \mathrm{C}$ for $4 \mathrm{~h}$ in a hydrogen atmosphere. Then the sintering samples were hot isostatic pressed at $1400{ }^{\circ} \mathrm{C}$ and $200 \mathrm{MPa}$ for $1 \mathrm{~h}$.

\subsection{Measurement, experimental procedures, and analysis}

The microstructure, composition and crystal structure of alloys were analyzed by EGA-SBH Scanning Electron Microscope (SEM) equipped with EDX detector and the high-resolution electron microscope (HRTEM).

The fabricated alloy' density was determined based on the Archimedes principle. The HVS-1000A tester was employed to analyze the Vickers hardness of alloys using a $200 \mathrm{~g}$ load for 10s. Compressive properties of alloy were tested using a AG-I250KN material machine at room temperature. The compression rate is $1.0 \mathrm{~mm} / \mathrm{min}$. Hot compression tests for alloy were carried out on a Gleeble-1500D test machine at $1100{ }^{\circ} \mathrm{C}, 1200{ }^{\circ} \mathrm{C}, 1300{ }^{\circ} \mathrm{C}$, and $1400{ }^{\circ} \mathrm{C}$ for $3 \mathrm{~min}$, respectively.
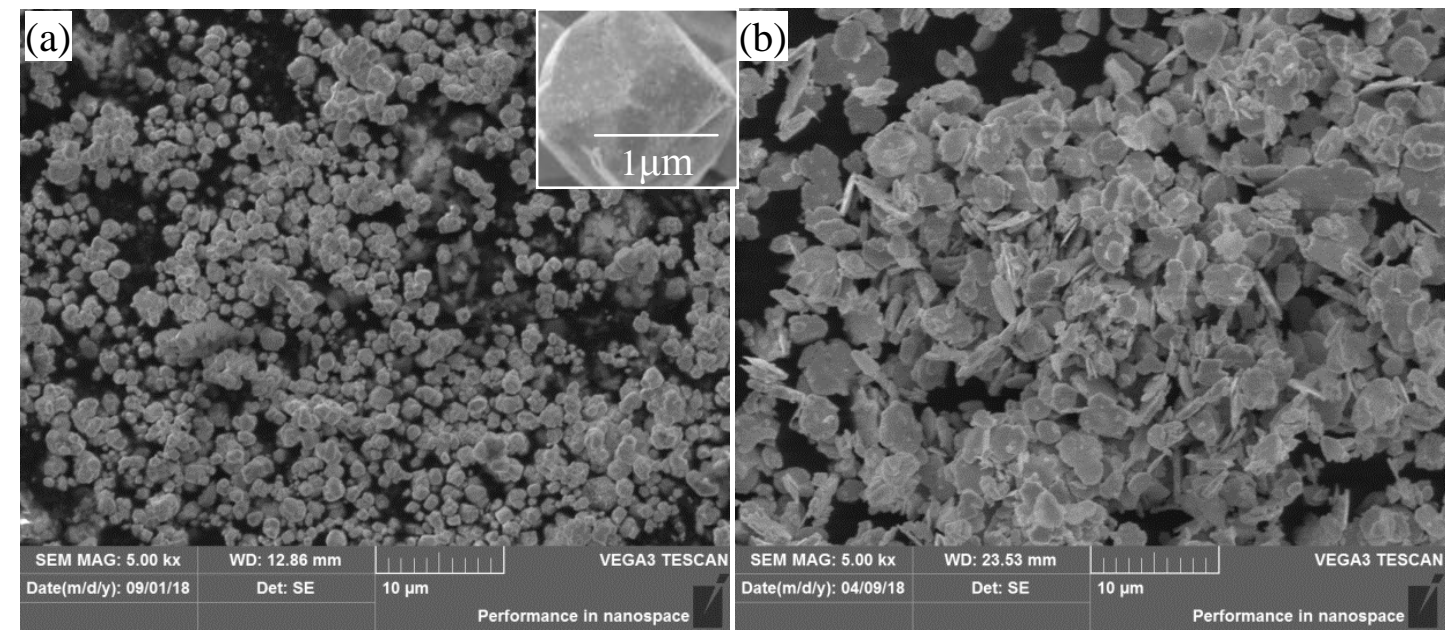

Fig. 1. SEM images of $\mathrm{W}-0.75 \mathrm{wt} \% \mathrm{Zr}(\mathrm{Y}) \mathrm{O}_{2}$ powders prepared through different methods: (a) Hydrothermal method; (b) Hydrothermal method, followed by mechanical alloying.

\section{Results and analysis}

\subsection{Microstructure of alloy}

Seen from SEM images in Fig. 2, the grains of the $\mathrm{W}-\mathrm{Zr}(\mathrm{Y}) \mathrm{O}_{2}$ alloys become finer with increasing $\mathrm{Zr}(\mathrm{Y}) \mathrm{O}_{2}$ mass fraction. The cause is that oxide particles not only refine tungsten powders during hydrogen reduction, but also pin grain boundary and impede the growth of grains in the sintering process [17]. Detailed examination shows that the refinement effect is not obvious with increasing of $\mathrm{Zr}(\mathrm{Y}) \mathrm{O}_{2}$ mass fraction 
from $0.25 \%$ to $0.75 \mathrm{wt} . \%$. Especially, as listed in Table 2, there are similar grains with an average size of about $5 \mu \mathrm{m}$ in $\mathrm{W}-0.5 \% \mathrm{Zr}(\mathrm{Y}) \mathrm{O}_{2}$ and $\mathrm{W}-0.75 \mathrm{wt} \% \mathrm{Zr}(\mathrm{Y}) \mathrm{O}_{2}$ alloys, this may be caused by the dispersed distribution of the tiny amount of $\mathrm{Zr}(\mathrm{Y}) \mathrm{O}_{2}$ particles in tungsten matrix.

BSE image in Fig. 3a reveals that few black particles are located at grain boundaries, which weaken the refinement effect. In contrast, most ultrafine $\mathrm{Zr}(\mathrm{Y}) \mathrm{O}_{2}$ particles are homogeneously distributed within the grains. These particles can generate, hinder and then accumulate dislocations in the grains during the deformation process. According to our previous research [27], owing to the addition of the tiny amount of $\mathrm{Zr}(\mathrm{Y}) \mathrm{O}_{2}$ (the doping amount is less than $0.75 \%$ ), no diffraction peaks of containing-Zr phases can be found in XRD patterns. However, the sintering tungsten alloys were composed of $\mathrm{ZrO}_{2}$ and $\mathrm{W}$ phases from the doped tungsten powders as shown in Fig. 5e of the reference [14]. As mentioned above, a large amount of black particles were uniformly distributed in the tungsten matrix. The composition of black particles were determined by EDS analysis, which are rich in $\mathrm{Zr}, \mathrm{Y}$ and $\mathrm{O}$ elements. Thus, these black particles with spherical appearance probably are $\mathrm{Zr}(\mathrm{Y}) \mathrm{O}_{2}$ particles. Fig. 3c shows the the particle size distribution, with Gaussian Fit on the histogram, are in a state of normal distribution based on 200 particles. Over $90 \%$ of particles range from $100 \mathrm{~nm}$ to $650 \mathrm{~nm}$ in diameter without the coarse particle of more than 1 $\mu \mathrm{m}$. The average particle size is about $410 \mathrm{~nm}$. In fact, lots of nanosized oxide particles less than $50 \mathrm{~nm}$ cannot easily be observed through SEM observation. Ultrafine and uniformed-size $\mathrm{Zr}(\mathrm{Y}) \mathrm{O}_{2}$ particles uniformly dispersed in the tungsten matrix may be due to the powder preparation process. As shown in Fig. 1a, the surfaces of the powder particles are covered with white substances. EDS analysis reveals that these white substances are rich in $\mathrm{Zr}$ and $\mathrm{Y}$ elements, belonging to the containing-(Zr, Y) substance. By high-energy ball-milling technique, the white containing-(Zr, Y) substances and tungsten powder particles not only were refined, but also would be dispersed into smaller particles. After sintering, these containing-(Zr, Y) substances would transform into the dispersive and ultrafine $\mathrm{Zr}(\mathrm{Y}) \mathrm{O}_{2}$ particles. 
Some oxide dispersion-strengthened tungsten alloys prepared through the hydrothermal method and mechanical alloying were listed in Table 3, respectively. Wang et al. $[18,28]$ prepared the $\mathrm{W}-\mathrm{Al}_{2} \mathrm{O}_{3}$ powders by hydrothermal method. After SPS and conventional $\mathrm{H}_{2}$ sintering, respectively, the average size of $\mathrm{Al}_{2} \mathrm{O}_{3}$ particles existed in their alloys reach to $1.5 \mu \mathrm{m}$ and $2.0 \mu \mathrm{m}$, as shown in Fig. 3d. Moreover, with the increasing of the doping amount, these $\mathrm{Al}_{2} \mathrm{O}_{3}$ particles agglomerate together and have bad bonding interface with their tungsten matrix, leading to high porosity and bad mechanical properties of the alloys. Li et al. [29] prepared $\mathrm{W}-2 \mathrm{wt} \% \mathrm{ZrO}_{2}$ by vertical sintering $\left(2700{ }^{\circ} \mathrm{C}\right)$ combined with the hot swaging process. Though the high sintering temperature closing to the melting point of $\mathrm{ZrO}_{2}$ and extremely short duration contribute to obtain the $\mathrm{ZrO}_{2}$ particle size, the dispersive $\mathrm{ZrO}_{2}$ particles still reach to $1.5 \mu \mathrm{m}$ in size and the tungsten grains grow up to $80-150 \mu \mathrm{m}$. For mechanical alloying of ODS-W powders, the refinement effect on oxide particle size is also limited even through doping nanosized oxide particles. Angel Muñoz et al. [30] prepared the $\mathrm{W}-\mathrm{La}_{2} \mathrm{O}_{3}$ powder using nanosized $\mathrm{La}_{2} \mathrm{O}_{3}$ particles ranging from 10 to 50 $\mathrm{nm}$ in size as raw material. However, the large adsorption effect of nanosized oxide particles leads to forming particle aggregations even after ball-milling for 30 hours [31]. Similar cases can be found in references [32-34]. In this work, the uniformed-size and ultrafine particles in the tungsten alloy were obtained, indicating the combining of adopted liquid-liquid doping and mechanical alloying is the appropriate to reduce the particles size.

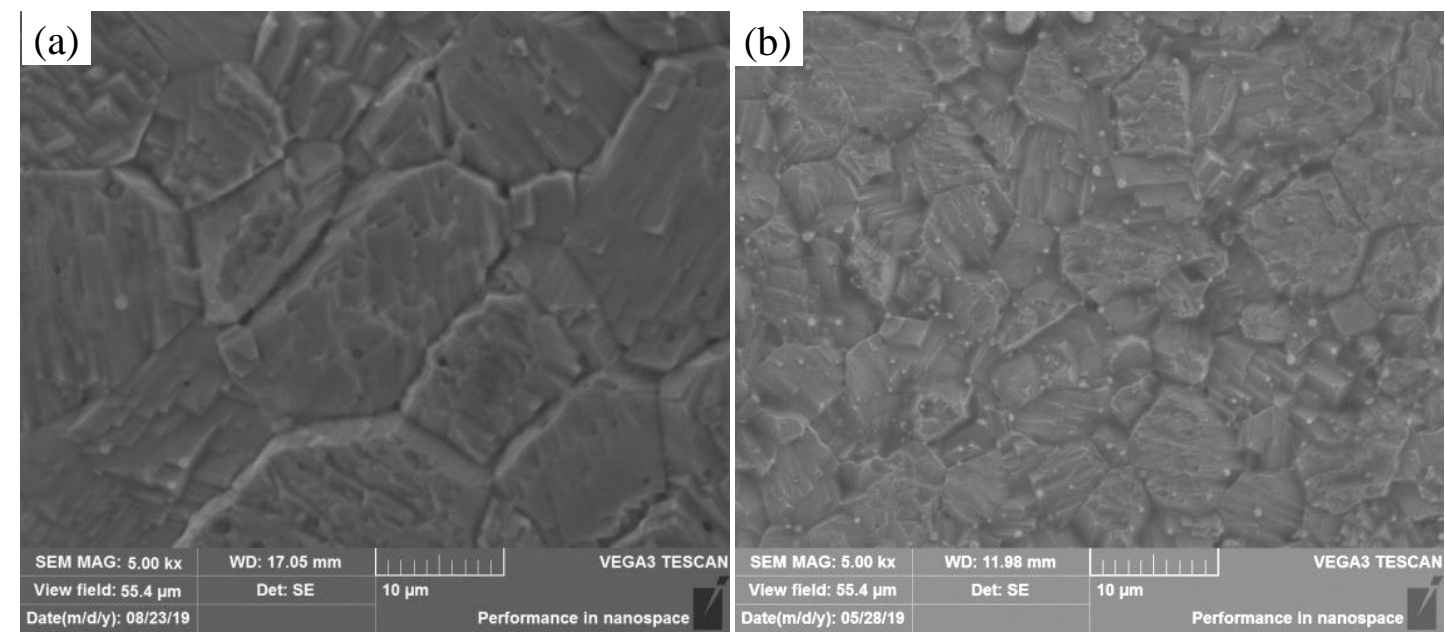



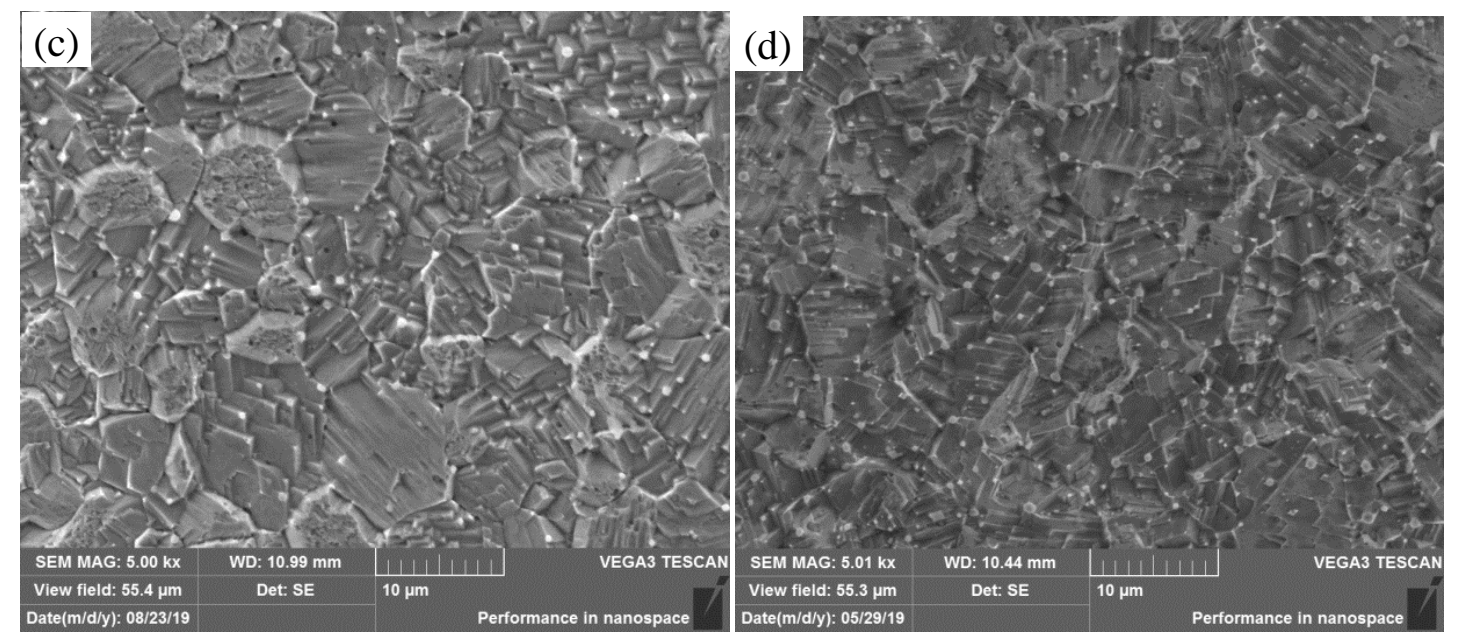

Fig. 2. Microstructure of alloys: (a) Pure W; (b) $\mathrm{W}-0.25 \mathrm{wt} \% \mathrm{Zr}(\mathrm{Y}) \mathrm{O}_{2}$; (c) $\mathrm{W}-0.5 \mathrm{wt} \% \mathrm{Zr}(\mathrm{Y}) \mathrm{O}_{2} ;$ (d) W-0.75wt $\% \mathrm{Zr}(\mathrm{Y}) \mathrm{O}_{2}$.
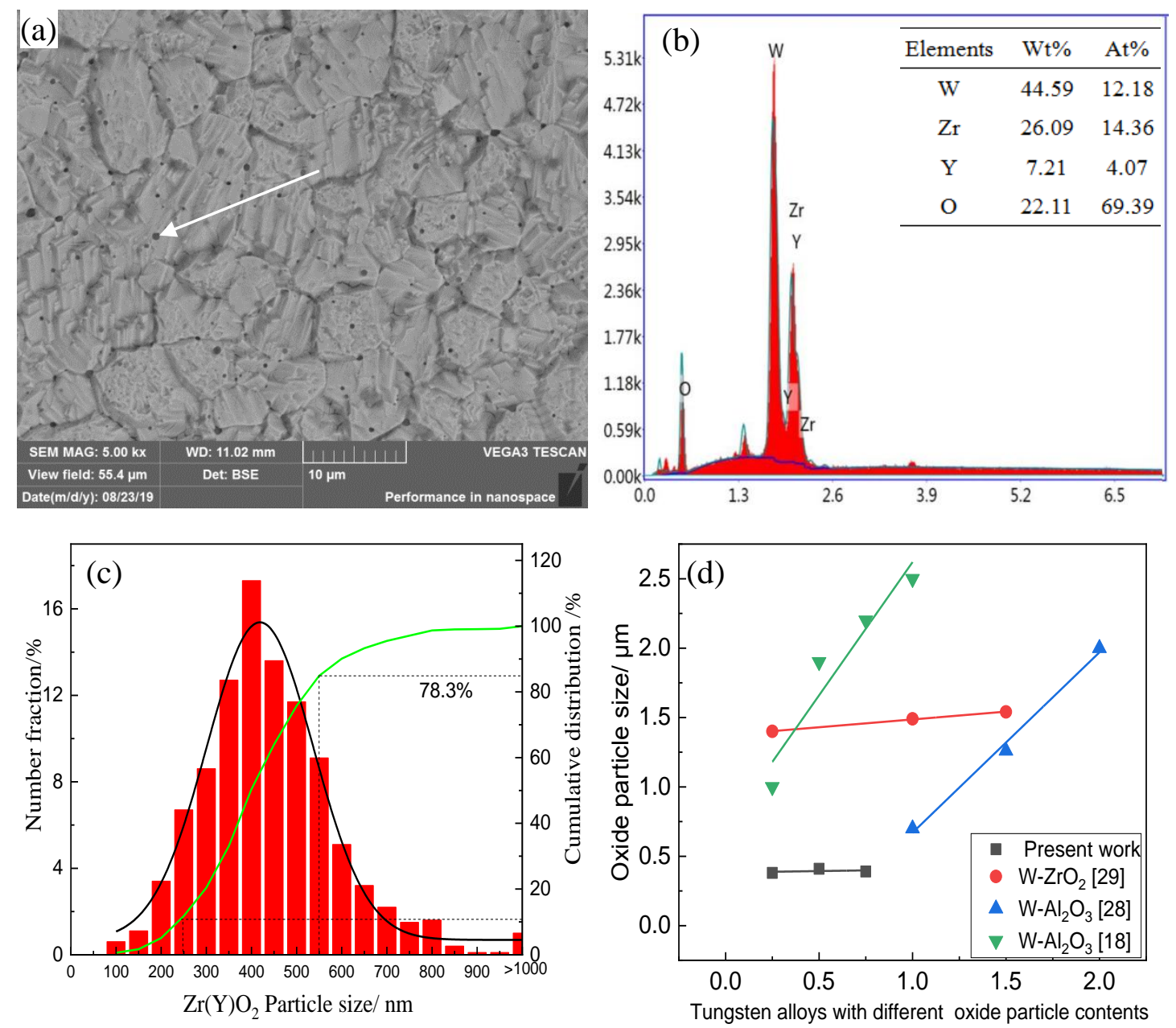

Fig. 3. (a) BSE image of tungsten alloys with $0.5 \mathrm{wt} \% \mathrm{Zr}(\mathrm{Y}) \mathrm{O}_{2}$ alloy; (b) EDS spectrum on the white arrow A in Fig. 3a; (c) Particle size distribution of $\mathrm{Zr}(\mathrm{Y}) \mathrm{O}_{2}$ in $\mathrm{W}-0.5 \mathrm{wt} \% \mathrm{Zr}(\mathrm{Y}) \mathrm{O}_{2}$ alloy and (d) Particle size VS W alloys reinforced different 
particle contents.

TEM was performed to characterize the microstructures of the prepared $\mathrm{W}-\mathrm{Zr}(\mathrm{Y}) \mathrm{O}_{2}$ alloy. As shown in Fig. 4(a, b), lots of nanosized oxide particles ( marked by orange arrows ) are in range of 25-100 nm under TEM observation. Some nanosized particles tend to aggregate (Fig. 4b). The selected area electron diffraction pattern (SAEDP) reveals that the $\mathrm{Zr}(\mathrm{Y}) \mathrm{O}_{2}$ particle exhibits a face-centered cubic (fcc) structure with a zone axis of [-112]. HRTEM images show the lattice spacing of $2.9646 \AA$ and $1.8152 \AA$ in cubic $\mathrm{ZrO}_{2}$ phase. As $\mathrm{ZrO}_{2}$ phase without stabilizer is monoclinic structure at room temperature [26], the detection of cubic phase $\mathrm{ZrO}_{2}$ confirms the $\mathrm{Y}_{2} \mathrm{O}_{3}$ has a stabilizing effect on $\mathrm{ZrO}_{2}$ phase. The existence of stabilized cubic phase $\mathrm{Zr}(\mathrm{Y}) \mathrm{O}_{2}$ also indicates that the formation of micro-cracks caused by volume change due to $\mathrm{ZrO}_{2}$ phase transitions would be avoided during the alloy cooling to room temperature. SADP image from selected area ( black box in Fig. 4b) was identified as cubic $\alpha-\mathrm{W}$ phase with a zone axis of [-113]. Moreover, dislocation lines and loops pointed by white arrows were also observed in tungsten grains or around oxide particles. Fig. 4c shows that the particles exhibit a good bonding with the tungsten phase. Meanwhile, the HRTEM image also shows the presence of amorphous structure area in the interfaces with about $2 \mathrm{~nm}$ wide, which may be caused by diffusion of containing-Zr phase into the $\mathrm{W}$ phase during high temperature sintering. The inset in Fig. 4d shows the magnified images of interface, from which, it can be seen that there are not coherent relation between tungsten phase and oxide phase.

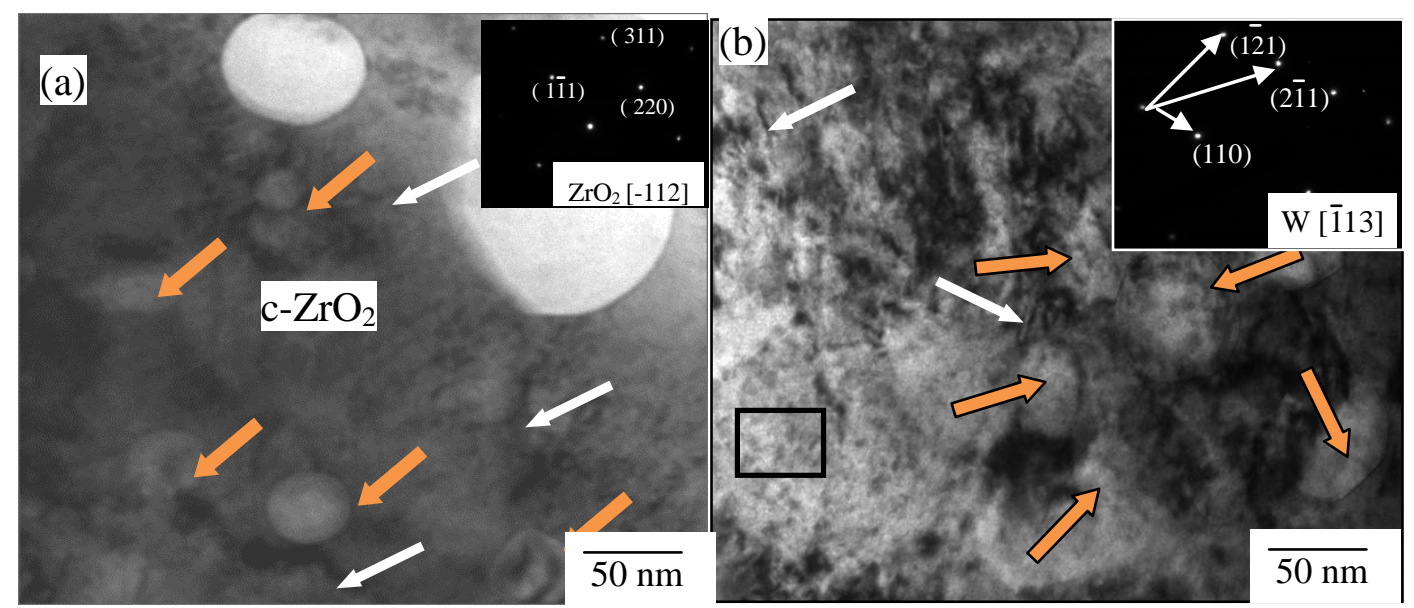

(c) 


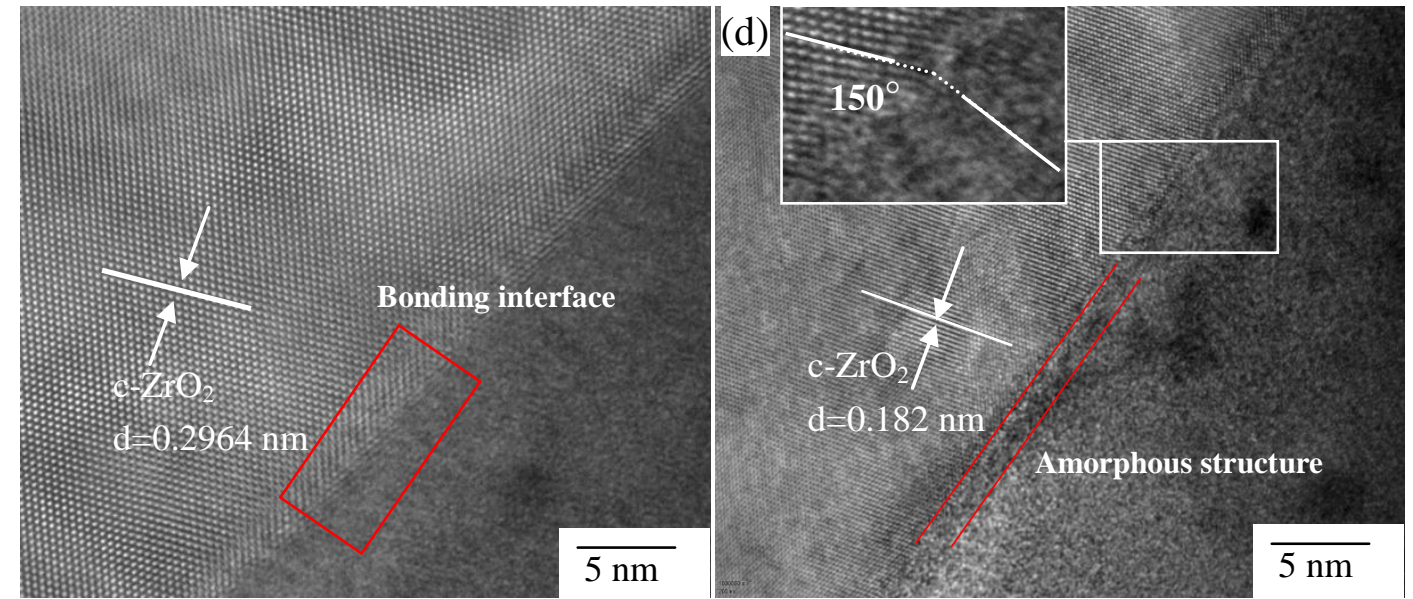

Fig. 4(a, b) TEM images of tungsten alloy showing $\mathrm{Zr}(\mathrm{Y}) \mathrm{O}_{2}$ particles; (c) HREM image of tungsten alloy; (d) HREM image of $\mathrm{Zr}(\mathrm{Y}) \mathrm{O}_{2} / \mathrm{W}$ interface

Table 2 Microstructure and mechanical properties of alloys.

\begin{tabular}{|c|c|c|c|c|c|}
\hline \multirow{2}{*}{ Sam. } & \multirow{2}{*}{$\begin{array}{l}\text { Grain /oxide } \\
\text { particle size } \\
(\mu \mathrm{m})\end{array}$} & \multirow{2}{*}{$\begin{array}{l}\text { Density } \\
\left(\mathrm{g} / \mathrm{cm}^{3}\right) / \\
(\% \mathrm{RD})^{\mathrm{a}^{*}}\end{array}$} & \multirow{2}{*}{$\begin{array}{l}\text { Vickers } \\
\text { hardness } \\
\text { /HV }\end{array}$} & \multicolumn{2}{|c|}{ Compressive strength $(\mathrm{MPa}) /$ fracture strain } \\
\hline & & & & $25^{\circ} \mathrm{C}$ & $1200^{\circ} \mathrm{C}$ \\
\hline Pure W & $10.5 /-$ & $18.238 / 94.5$ & 378 & $1260 / 0.185$ & 438.6/- \\
\hline $\mathrm{W}_{0.25}$ & $6.5 / 0.31$ & $18.281 / 95.3$ & 456 & $1577 / 0.262$ & $492.5 /-$ \\
\hline $\mathrm{W}_{0.50}$ & $5.6 / 0.41$ & $18.291 / 95.9$ & 467 & $1420 / 0.223$ & $533.7 /-$ \\
\hline $\mathrm{W}_{0.75}$ & $4.3 / 0.38$ & $18.311 / 96.5$ & 486 & $1350 / 0.215$ & $516.1 /-$ \\
\hline
\end{tabular}

a* Relative density [14].

Table 3 Microstructures and properties of ODS-W alloys.

\begin{tabular}{c|c|c|c|c|c|c|c}
\hline \multirow{2}{*}{$\begin{array}{c}\text { Methods } \\
\text { Alloy }\end{array}$} & Process & $\begin{array}{c}\text { W grain } \\
\text { size }(\mu \mathrm{m})\end{array}$ & $\begin{array}{c}\text { Oxide particle } \\
\text { size }(\mu \mathrm{m})\end{array}$ & $\begin{array}{c}\text { Density } \\
\left(\mathrm{g} / \mathrm{cm}^{3}\right) /(\% \\
\mathrm{RD})\end{array}$ & $\begin{array}{c}\text { Microhardness } \\
/ \mathrm{HV}\end{array}$ & Refs. \\
\hline \multirow{4}{*}{$\begin{array}{c}\text { mechanically } \\
\text { alloyed }\end{array}$} & $\mathrm{W}-1 \% \mathrm{La}_{2} \mathrm{O}_{3}$ & $\mathrm{HIP}$ & - & $>5$ & $18.9 / 90.6$ & - & {$[30]$} \\
\cline { 2 - 9 } & $\mathrm{W}-1 \% \mathrm{Y}_{2} \mathrm{O}_{3}$ & Sintering & 4 & 1.4 & $-/<18.5$ & 412.7 & {$[31]$} \\
\cline { 2 - 9 } & $\mathrm{W}-\mathrm{Ti}-0.5 \% \mathrm{Y}_{2} \mathrm{O}_{3}$ & $\mathrm{HIP}$ & $2-5$ & $>1$ & - & - & {$[32]$} \\
\cline { 2 - 9 }
\end{tabular}




\begin{tabular}{c|c|c|c|c|c|c|c}
\hline & $\mathrm{W}-5 \% \mathrm{HfO}_{2}$ & SPS & 11.6 & $>5$ & $-/ 94.5$ & 440 & {$[34]$} \\
\hline \multirow{4}{*}{$\begin{array}{c}\text { Hydrothermal } \\
\text { method }\end{array}$} & $\mathrm{W}-2.5 \% \mathrm{ZrO}_{2}$ & SPS & 4.65 & 2.5 & $-/ 99.6$ & 480 & {$[27]$} \\
\cline { 2 - 8 } & $\mathrm{W}-1.5 \% \mathrm{ZrO}_{2}$ & Swaging & $40-80$ & 1.5 & - & - & {$[29]$} \\
\cline { 2 - 9 } & $\mathrm{W}-1 \% \mathrm{Al}_{2} \mathrm{O}_{3}$ & $\begin{array}{c}\mathrm{H}_{2} \\
\text { sintering }\end{array}$ & 3 & $>2$ & $-1<96.5$ & 200 & {$[18]$} \\
\cline { 2 - 9 } & $\mathrm{W}-6 \mathrm{vol} \% \mathrm{Al}_{2} \mathrm{O}_{3}$ & $\mathrm{SPS}$ & 3.64 & $>1.0$ & -194.96 & 347.39 & {$[28]$} \\
\hline Present work & $\mathrm{W}-0.75 \% \mathrm{Zr}(\mathrm{Y}) \mathrm{O}_{2}$ & $\mathrm{HIP}$ & 4.3 & 0.38 & $18.31 / 96.5$ & 486 & \\
\hline
\end{tabular}

\subsection{Mechanical properties of alloys}

\subsubsection{Density and microhardness}

The density, microhardness and compressive properties at room and high temperatures are listed in Table 2. Although the theoretical densities decrease due to lower density of $\mathrm{Zr}(\mathrm{Y}) \mathrm{O}_{2}$ existed in the alloy, three $\mathrm{W}-\mathrm{Zr}(\mathrm{Y}) \mathrm{O}_{2}$ alloys all have higher densities compared to pure tungsten and their densities increase slightly with the increase in the $\mathrm{Zr}(\mathrm{Y}) \mathrm{O}_{2}$ mass fraction. On the one hand, the improvement of sinterability would be caused by abundant surface energy and grain boundary energy of ultrafine milled powder [35-37]. On the other hand, the dispersion of oxide particles can effectively inhibit pores and cracks, and greatly refine compactness [38]. However, alloys still exhibit lower relative densities, which are all below 97\%, owing to the existence of sintered defects in the alloys.

For the microhardness, the addition of $\mathrm{Zr}(\mathrm{Y}) \mathrm{O}_{2}$ increases the microhardness compared to pure tungsten. The microhardness of the $\mathrm{W}-\mathrm{Zr}(\mathrm{Y}) \mathrm{O}_{2}$ alloys increases with increasing of $\mathrm{Zr}(\mathrm{Y}) \mathrm{O}_{2}$ mass fraction. The higher microhardness may be due to the following reasons: On the one hand, the higher alloy' density and the smaller grain size mean the higher microhardness [39]; On the other hand, the dispersive nanosized $\mathrm{Zr}(\mathrm{Y}) \mathrm{O}_{2}$ particles, increase the dislocation density of the tungsten matrix and then strengthen the tungsten matrix, which contribute to the increase in hardness as well [40].

\subsubsection{Compressive properties of tungsten alloys}


The stress-strain curves of tungsten alloys during compressive deformation were shown in Fig. 5. Obviously, pure tungsten lacking strengthening phase has the lowest ultimate strength and fracture strain [39]. However, due to the lower porosity resulted from pressing sintering, the compressive strength and fracture strain of pure $\mathrm{W}$ in current research are $14.5 \%$ and $32.1 \%$, respectively, which are higher compared to the reported conventional sintering and SPSed pure $\mathrm{W}$ [27]. For $\mathrm{W}-\mathrm{Zr}(\mathrm{Y}) \mathrm{O}_{2}$ alloys, the influence of $\mathrm{Zr}(\mathrm{Y}) \mathrm{O}_{2}$ on the compressive properties is complicated. The $\mathrm{W}-0.25 \mathrm{wt} \% \mathrm{Zr}(\mathrm{Y}) \mathrm{O}_{2}$ alloy exhibits the highest strength of $1577 \mathrm{MPa}$ and fracture strain of 0.262 , approximately $25.2 \%$ and $40.5 \%$ higher than those of the pure W, respectively.

With the increase in the $\mathrm{Zr}(\mathrm{Y}) \mathrm{O}_{2}$ content, the strength and fracture strain continue to decrease. In $\mathrm{W}-0.75 \mathrm{wt} \% \mathrm{Zr}(\mathrm{Y}) \mathrm{O}_{2}$ alloy, the compressive strength and fracture strain decrease to $1350 \mathrm{MPa}$ and 0.215 , respectively. However, these alloys still exhibit high compressive properties. As shown in Fig. 5b and c, the transparent black areas show the compressive strength and fracture strain of $\mathrm{W}-\mathrm{Zr}(\mathrm{Y}) \mathrm{O}_{2}$ alloys in current research. It is obvious that the prepared alloys exhibit the higher compressive properties compared to the SPSed sintering and conventional sintering alloys reported in references $[18,27]$, respectively. For SPSed sintering alloy, generally, the smaller grains contribute to the improvement of properties. However, the lower quality powder results in the larger $\mathrm{ZrO}_{2}$ particles (Table 3) among tungsten alloys, leading to the poor microstructure and mechanical properties. It is easy to understand that, due to the pressureless sintering, the conventional sintering alloys exhibit lower compressive strength and fracture strain. Compared to the swaged W-(0-1.5\%) $\mathrm{ZrO}_{2}$ alloys [29], although hot swaging slightly improve the compressive properties, the large grains $(50-120 \mu \mathrm{m})$ and oxide particles (about $1.5 \mu \mathrm{m})$ resulted from high temperature sintering (nearly $2700{ }^{\circ} \mathrm{C}$ ), lead to the limited reinforcement effect on tungsten grains and lower fracture strain. 

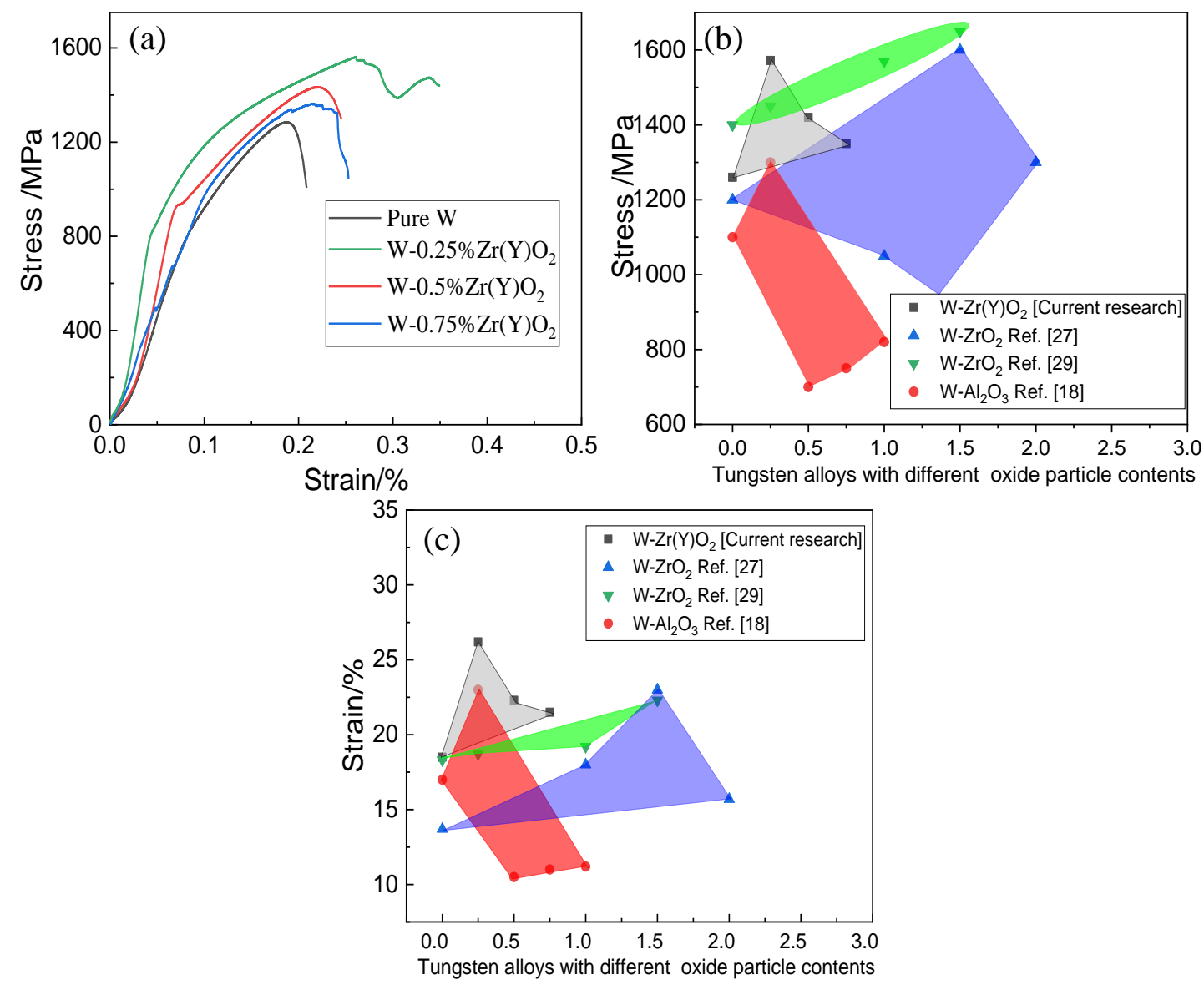

Fig. 5. (a) Compressive stress-strain curves of $\mathrm{W}$ alloys with different $\mathrm{Zr}(\mathrm{Y}) \mathrm{O}_{2}$ contents; (b) Compressive strength and (c) Fracture strain of $\mathrm{W}-\mathrm{Zr}(\mathrm{Y}) \mathrm{O}_{2}$ alloy in comparison with available literature datas.

The fracture surfaces of the fabricated $\mathrm{W}-0.25 \% \mathrm{Zr}(\mathrm{Y}) \mathrm{O}_{2}$ alloy are recorded in Fig. 6, for studying compressive fracture behavior of the alloy. A mixed mode failure can be observed, including the $\mathrm{W}$ intergranular failure, $\mathrm{W}$ grain cleavage and $\mathrm{W}$ grain tearing. Secondary cracks indicating failure of Wgrains are also evidenced in Fig. 6(a, c). Due to the limited pressure in HIPed sintering process, there are some pores in fracture surfaces. As shown in Fig. 6a, a very low area fraction of the smooth intergranular failure can be observed around the pores. These pores may be partially responsible for the brittle cleavage. When alloy is subjected to load, pores would form the preexisting sources for cracks, eventually hindering the further improvement of mechanical strength and ductility. During deformation, the fracture mode mainly consists of transgranular fracture. In Fig. 6b, which is the magnified image of the selected area in Fig. 6a, obvious river-line patterns confirm the presence of the 
transgranular failure in tungsten grains. In our previous research [17], though the $\mathrm{W}-1.5 \mathrm{wt} \% \mathrm{ZrO}_{2}$ alloy was also fabricated through HIP sintering, coarse oxide particles at GBs induce stress/strain concentration and cause interfacial decohesion at weaker GBs, resulting in the main intergranular pattern in alloys' fractures surface (Fig. 14a in ref. [39]). In present research, the ultrafine oxide particles evenly distributed in tungsten matrix (marked by the black particle in inset) may be the main reason obtaining the changed fracture pattern, through improving the fracture strength of the tungsten grains and GBs. In fact, during deforming, the fabricated alloy involves more plastic deformation, such as significant $\mathrm{W}$ grain tearing and grain deformations as shown in Fig. 6c and d. The strengthening effect of oxide particle on the fabricated alloy can be also evidenced by the presence of slip lines (Fig. 6b) as well as microdimples (Fig. 6d).
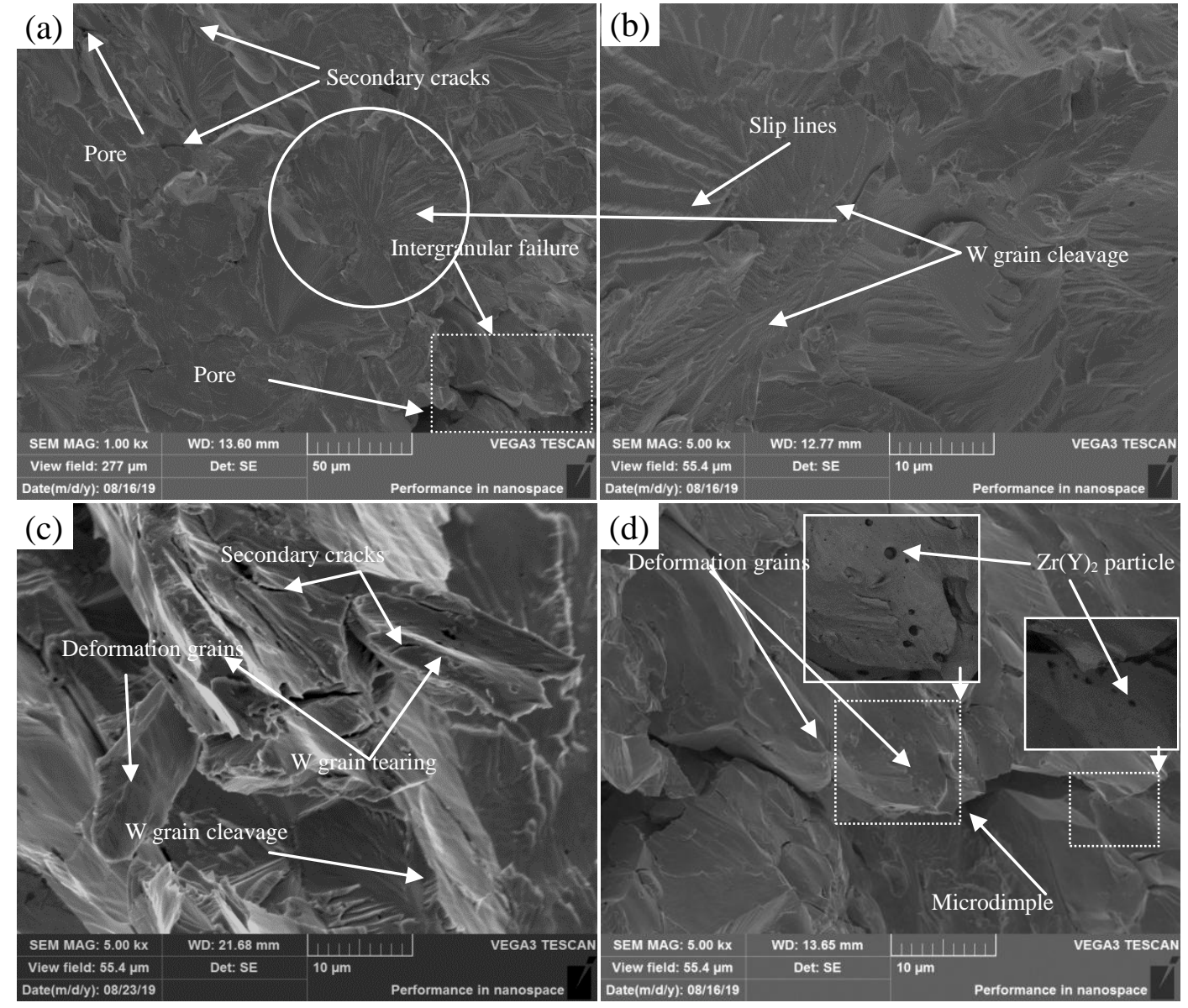

Fig. 6. Fracture surface of $\mathrm{W}-0.25 \% \mathrm{Zr}(\mathrm{Y}) \mathrm{O}_{2}$ alloy 
The stress-strain curves of tungsten alloy tested under different conditions were shown in Fig. 7. It was found that the flow stress increases with the increase of strain rate, while it decreases with the increase of deformation temperature. It indicates that the stress strongly depends on the strain rate and the deformation temperature. When tested at $1100{ }^{\circ} \mathrm{C}$ with strain rate of $0.1 \mathrm{~s}^{-1}$, the peak stress is $533.5 \mathrm{MPa}$. When the strain rate increases to $1 \mathrm{~s}^{-1}$, the peak stress increases to $577.4 \mathrm{MPa}$. Firstly, the heating time is not enough for material softening due to a relatively high deformation rate [41]. Secondly, the higher strain rate enhances the density of dislocations and the degree of work hardening. During deformation at a high strain rate, the work hardening cannot be completely eliminated [42, 43]. At a fixed strain rate, for example, when the strain rate is $0.1 \mathrm{~s}^{-1}$ and the temperature is $1200{ }^{\circ} \mathrm{C}$ (Table 2), the peak stress is $492.5 \mathrm{MPa}$. When the temperature increases to $1400{ }^{\circ} \mathrm{C}$, the peak value of stress is reduced to $437.7 \mathrm{MPa}$. At high temperature, the tungsten alloy contains a higher layer of stacking fault energy and the cross-slip easily occurs in the process of deformation, which makes it easier to soft for material and then reduces the resistance to deformation $[44,45]$.

In our previous research [16], due to the occurrence of dynamic recrystallization during hot working, the stress-strain curves of tungsten alloy after deformation at $1400{ }^{\circ} \mathrm{C}$ with a strain rate of $0.01 \mathrm{~s}^{-1}$ firstly increased to a peak value rapidly, and then decreased until it reached a relatively steady value. However, from Fig. 7, it can be seen that all the curves show the steady-state flow stress characteristics. In the given temperature and strain rate, the stress-strain curve seems to reach a horizontal line. This may be due to the presence of ultrafine $\mathrm{Zr}(\mathrm{Y}) \mathrm{O}_{2}$ particles in alloys. The homogeneous dispersion of oxide nano-particles in tungsten alloy could pin dislocations and grain boundaries, and thus inhibit the grain growth, enhancing the high temperature strength and improving the recrystallization temperature [46]. 


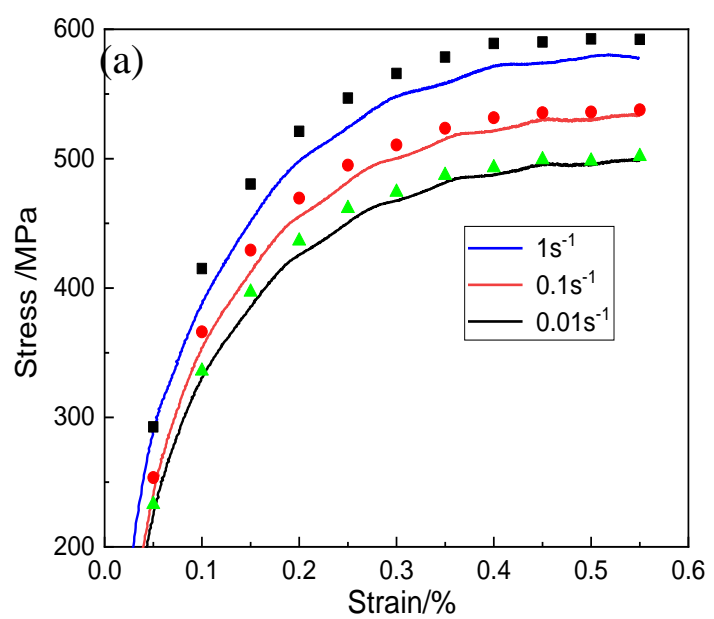

(a) $1100{ }^{\circ} \mathrm{C}$

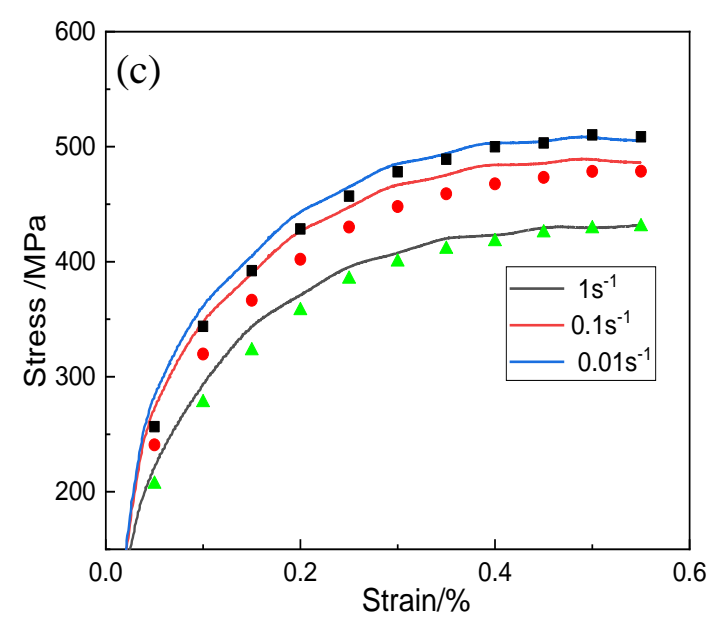

(c) $1300{ }^{\circ} \mathrm{C}$

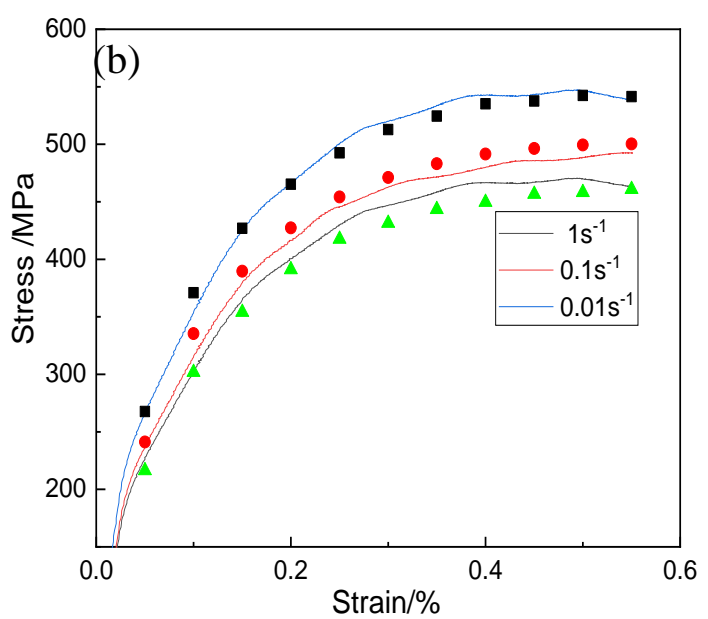

(b) $1200{ }^{\circ} \mathrm{C}$

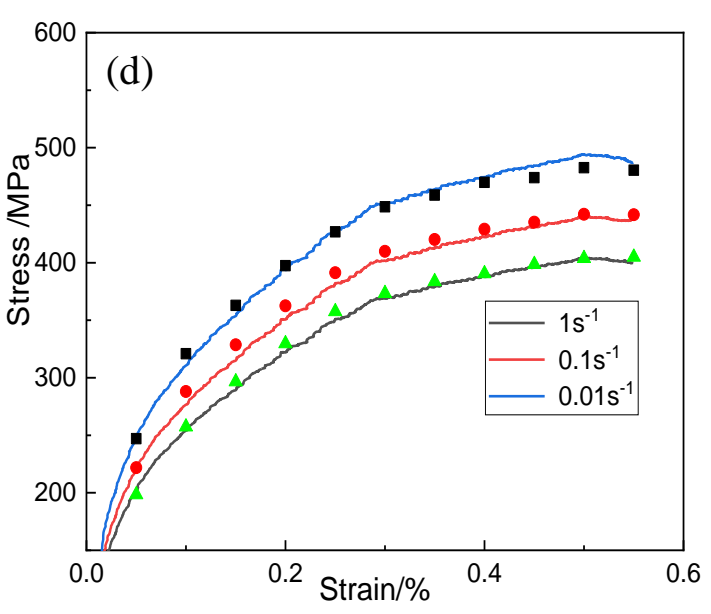

(d) $1400{ }^{\circ} \mathrm{C}$

Fig. 7. True stress-strain curves of the $\mathrm{W}-0.25 \mathrm{wt} \% \mathrm{Zr}(\mathrm{Y}) \mathrm{O}_{2}$ alloy under different deformation conditions: (a) $1100{ }^{\circ} \mathrm{C}$; (b) $1200{ }^{\circ} \mathrm{C}$; (c) $1300{ }^{\circ} \mathrm{C}$; (d) $1400{ }^{\circ} \mathrm{C}$.

\section{Deformation constitutive model}

\subsection{Establishment of the constitutive model}

In this model, the relationship among the strain rate $\left(\dot{\varepsilon} / \mathrm{s}^{-1}\right)$, flow stress $(\sigma / \mathrm{MPa}$ for a given strain of 0.55) and temperature (K), was established through the Arrhenius model [47], as it usually is employed to predict the deformation behavior of alloys under different deformation conditions [48]. The establishment of the Arrhenius model is based on the following equations (Eqs:1-3).

$$
\begin{array}{ll}
\dot{\varepsilon}=A(\sinh (\alpha \sigma))^{\mathrm{n}} \exp (-Q / R T) & \text { for all } \alpha \sigma \\
\dot{\varepsilon}=A_{1} \sigma^{n_{1}} \exp (-Q / R T) & \alpha \sigma<0.8 \\
\dot{\varepsilon}=A_{2} \exp (\beta \sigma) \exp (-Q / R T) & \alpha \sigma>1.2
\end{array}
$$


Where, $\mathrm{R}$ is the universal gas constant $\left(8.314 \mathrm{~J} \mathrm{~mol}^{-1} \mathrm{~K}^{-1}\right)$; $\mathrm{Q}$ is the activation energy of hot deformation $\left(\mathrm{KJ} \mathrm{mol}^{-1}\right) ; \mathrm{A}, \mathrm{A}_{1}, \mathrm{~A}_{2}, \mathrm{n}, \mathrm{n}_{1}, \beta$ and $\alpha$ are all the correlative materials constant and $\alpha=\beta / \mathrm{n}_{1}$.

As the deformation temperature and strain rate both affect the deformation behavior [49], the Zener-Hollomon parameter (Z), which means the deformation rate factor of temperature compensation, was used to reveal the coupling effects of strain rate and temperature on flow stress [50]:

$$
Z=\dot{\varepsilon} \exp (\mathrm{Q} / \mathrm{RT})=\mathrm{A}[\sinh (\alpha \sigma)]^{\mathrm{n}}
$$

When deformation temperature is fixed, after introducing Eq. (4) into Eqs. (1)-(3), we can obtain the following equations (5-8):

$$
\begin{aligned}
& \ln \dot{\varepsilon}=\ln A_{1}+\mathrm{n}_{1} \ln \sigma-\mathrm{Q} / \mathrm{RT} \\
& \ln \dot{\varepsilon}=\ln A_{2}+\beta \sigma-\mathrm{Q} / \mathrm{RT} \\
& \ln \dot{\varepsilon}=A+\mathrm{n} \ln [\sinh (\alpha \sigma)] \\
& \mathrm{Q}=\left.\left.R \frac{\partial \ln \dot{\varepsilon}}{\partial \ln [\sinh (\alpha \sigma)]}\right|_{T} \frac{\partial \ln [\sinh (\alpha \sigma)]}{\partial(1 / T)}\right|_{\dot{\varepsilon}}=\mathrm{Rnb}
\end{aligned}
$$

Where the $\mathrm{n}_{1}$ and $\beta$ can be calculated from the slope of $\ln (\sigma)-\ln (\dot{\varepsilon})$ plot and $\sigma-\ln (\dot{\varepsilon})$ plot, respectively, as shown in Fig. 8. These lines are almost parallel, indicating that the slopes of the lines vary in a very small range. The slight variation in the slopes of these lines may be attributed to scattering in the hot compression experimental data. The calculated mean values of $n_{1}$ and $\beta$ are 26.79518 and 0.0588 , respectively. Then, the $\alpha$ values can be determined to be 0.002194 . The values of $n$ and $b$, is the slopes of $\ln \dot{\varepsilon}-\ln [\sinh (\alpha \sigma)]$ and $1000 / \mathrm{T}-\ln [\sinh (\alpha \sigma)]$ plots as shown in Fig. 9, which are 21.42387667, and 1.98223, respectively. Thus the value of Q (activation energy) is $\mathrm{Rnb}=353.0710624 \mathrm{~kJ} / \mathrm{mol}$.

The Eq.(9) can be obtained from taking the logarithm of Eq. (4):

$$
\ln Z=\ln A+\mathrm{n}[\sinh (\alpha \sigma)]
$$

The values of $\ln \mathrm{A}$ and $\mathrm{n}$ could be obtained from the intercept and line slope of the $\ln [\sinh (\alpha \sigma)]-\ln Z$ as shown in Fig. 10, which is 20.54226 and 20.78805, respectively. By substituting the values of the material constants A, n, Q and $\alpha$ into equations (1), the relationship between strain rate and temperature of the $\mathrm{W}-0.25 \mathrm{wt} \% \mathrm{Zr}(\mathrm{Y}) \mathrm{O}_{2}$ alloy 
at a strain of 0.55 can be expressed as:

$$
\dot{\varepsilon}=8.34 \times 10^{8}[\sinh (0.002194 \sigma)]^{20.78805} \exp \left(\frac{353.07106}{\mathrm{RT}}\right)
$$
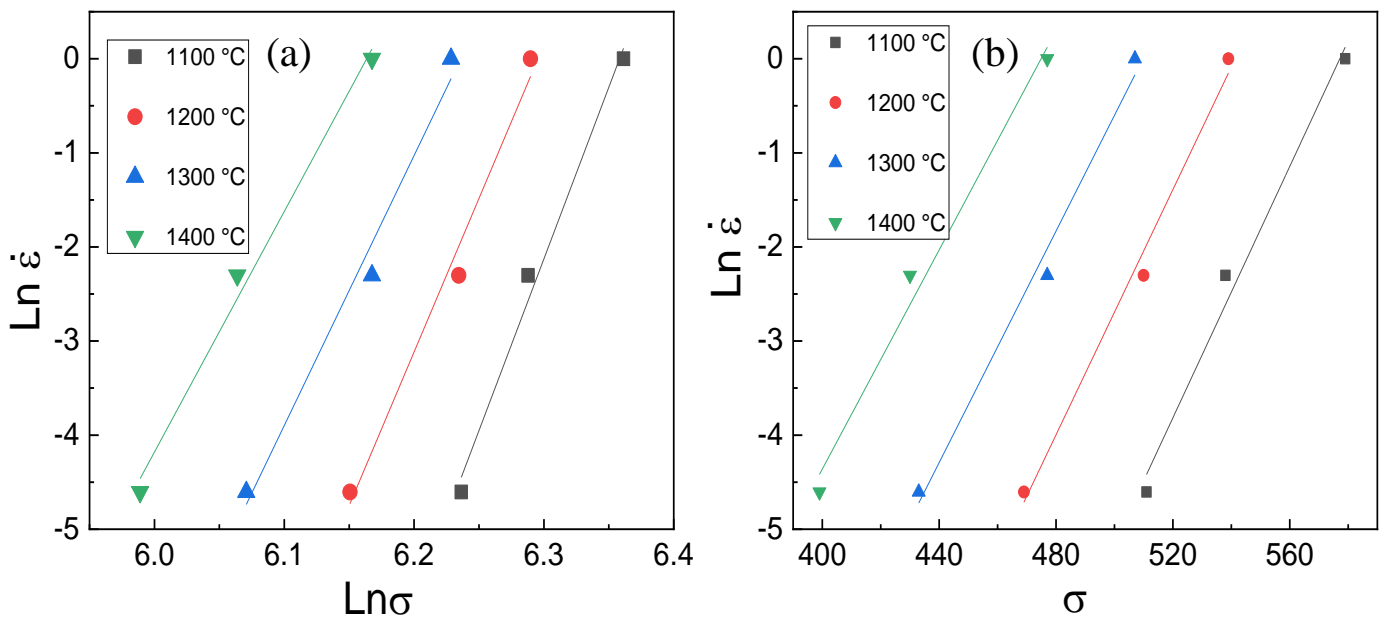

Fig. 8. Relationships between: (a) $\ln \sigma-\ln \dot{\varepsilon}$; (b) $\sigma-\ln \dot{\varepsilon}$.
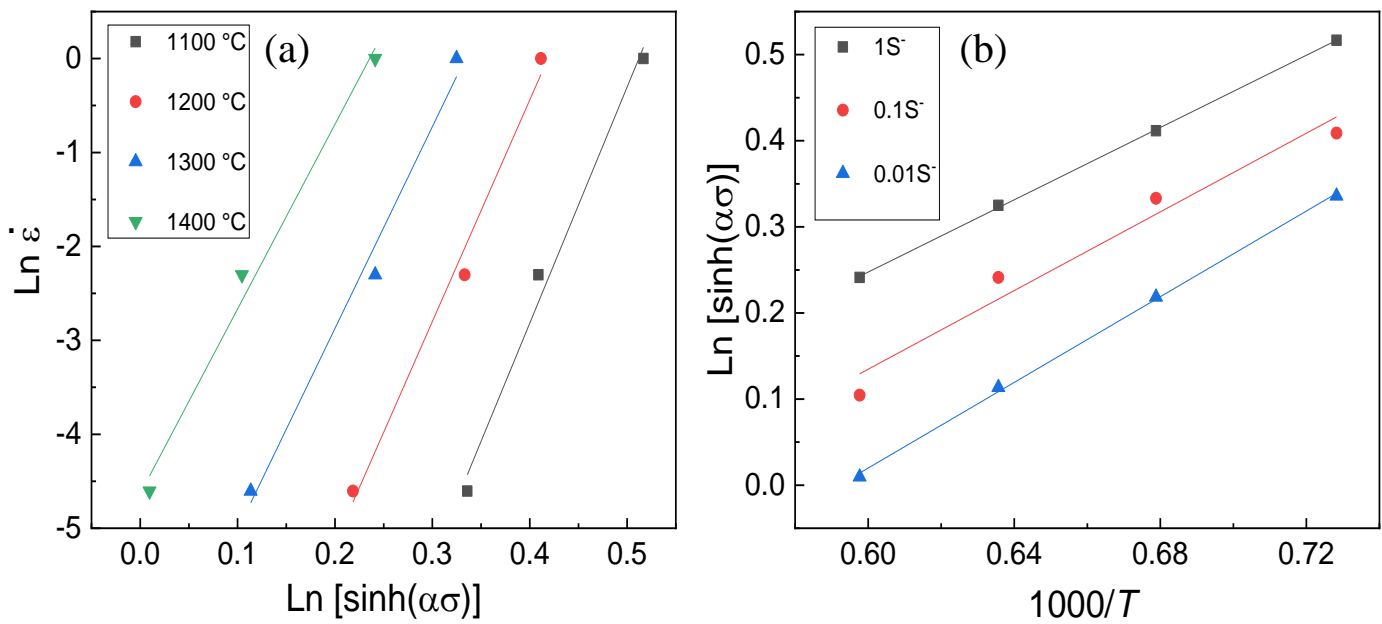

Fig. 9. Relationship between: (a) $\ln [\sinh (\alpha \sigma)]-\ln \dot{\varepsilon}$; (b) $\ln [\sinh (\alpha \sigma)]-1000 / \mathrm{T}$.

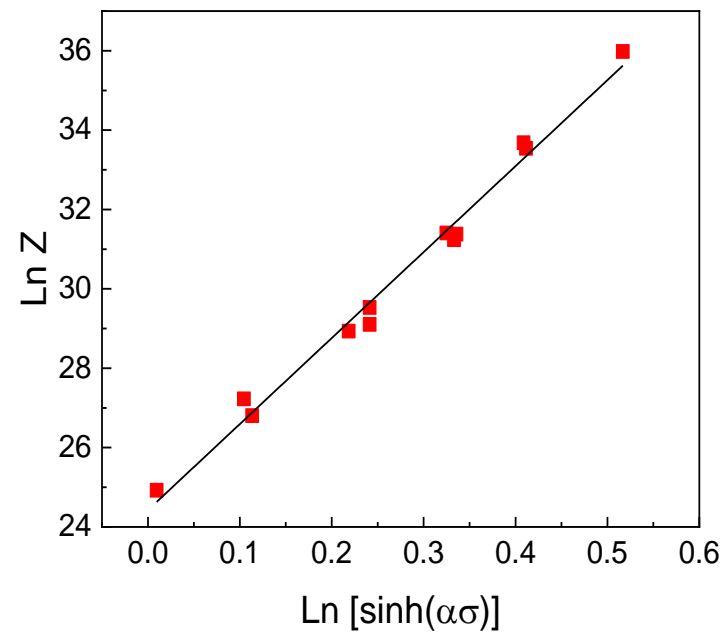

Fig. 10 Relationship between $\ln [\sinh (\alpha \sigma)]$ and $\ln Z$. 


\subsection{Compensation for strain}

It was reported that the strain obviously affected greatly the material constants (a, $\mathrm{n}, \mathrm{Q}, \ln \mathrm{A})$ at evaluated temperature $[42,47]$. Therefore, compensation of strain should be taken into account in order to establish constitutive equations to predict the flow stress more accurately. In this study, the material constant values under different strains were calculated within the range of $0.05-0.55$ and the interval of 0.05 . The different material constants at different strains were plotted in Fig. 11. The sixth order polynomial fitting Eq. (11) was employed to describe the relationship between material parameters and strain. The calculated coefficients are listed in Table 4.

$$
\begin{aligned}
& \alpha=A_{0}+A_{1} \varepsilon+A_{2} \varepsilon^{2}+A_{3} \varepsilon^{3}+A_{4} \varepsilon^{4}+A_{5} \varepsilon^{5}+A_{6} \varepsilon^{6} \\
& \mathrm{n}=\mathrm{B}_{0}+\mathrm{B}_{1} \varepsilon+\mathrm{B}_{2} \varepsilon^{2}+\mathrm{B}_{3} \varepsilon^{3}+\mathrm{B}_{4} \varepsilon^{4}+\mathrm{B}_{5} \varepsilon^{5}+\mathrm{B}_{6} \varepsilon^{6} \\
& \mathrm{Q}=\mathrm{C}_{0}+\mathrm{C}_{1} \varepsilon+\mathrm{C}_{2} \varepsilon^{2}+\mathrm{C}_{3} \varepsilon^{3}+\mathrm{C}_{4} \varepsilon^{4}+\mathrm{C}_{5} \varepsilon^{5}+\mathrm{C}_{6} \varepsilon^{6} \\
& \ln \mathrm{A}=\mathrm{DA}_{0}+\mathrm{D}_{1} \varepsilon+\mathrm{D}_{2} \varepsilon^{2}+\mathrm{D}_{3} \varepsilon^{3}+\mathrm{D}_{4} \varepsilon^{4}+\mathrm{D}_{5} \varepsilon^{5}+\mathrm{D}_{6} \varepsilon^{6}
\end{aligned}
$$

Table. 4 Fitting values of parameters of the Arrhenius equation.

\begin{tabular}{|l|r|l|r|l|l|l|r|}
\hline \multicolumn{2}{|c|}{$\alpha / 10^{-3}$} & \multicolumn{3}{c|}{$\mathrm{n}$} & \multicolumn{3}{c|}{$\mathrm{Q}$} \\
\hline $\mathrm{A}_{0}$ & 4.38 & $\mathrm{~B}_{0}$ & -397.059 & $\mathrm{C}_{0}$ & 61.83677 & $\mathrm{D}_{0}$ & 11.85768 \\
\hline $\mathrm{A}_{1}$ & -11.4 & $\mathrm{~B}_{1}$ & 4639.339 & $\mathrm{C}_{1}$ & 780.7316 & $\mathrm{D}_{1}$ & -233.666 \\
\hline $\mathrm{A}_{2}$ & -41.67 & $\mathrm{~B}_{2}$ & -23722.6 & $\mathrm{C}_{2}$ & 52798.31 & $\mathrm{D}_{2}$ & 6874.381 \\
\hline $\mathrm{A}_{3}$ & 497.23 & $\mathrm{~B}_{3}$ & 61010.93 & $\mathrm{C}_{3}$ & -472133 & $\mathrm{D}_{3}$ & -49872.5 \\
\hline $\mathrm{A}_{4}$ & -1594.39 & $\mathrm{~B}_{4}$ & -77576.4 & $\mathrm{C}_{4}$ & 1608510 & $\mathrm{D}_{4}$ & 158141.4 \\
\hline $\mathrm{A}_{5}$ & 2225.9 & $\mathrm{~B}_{5}$ & 38869.61 & $\mathrm{C}_{5}$ & -2461810 & $\mathrm{D}_{5}$ & -233247 \\
\hline $\mathrm{A}_{6}$ & -1161.89 & $\mathrm{~B}_{6}$ & -397.059 & $\mathrm{C}_{6}$ & 1414360 & $\mathrm{D}_{6}$ & 130896.2 \\
\hline
\end{tabular}

By rearranging Eq. (4), the predicted flow stress can be calculated by a function of the Zener-Hollomon parameter as shown in Eq. (12).

$$
\sigma=\frac{1}{\alpha} \ln \left\{\left(\frac{\mathrm{Z}}{\mathrm{A}}\right)^{1 / \mathrm{n}}+\left[\left(\frac{\mathrm{Z}}{\mathrm{A}}\right)^{2 / \mathrm{n}}+1\right]^{1 / 2}\right\}
$$

The comparison of the experimental and predicted flow stress datas in all test deformation conditions is shown in Fig. 5. The results show a good agreement between the calculated datas and the experimental datas. Only in some deformation conditions (i.e. at $1100{ }^{\circ} \mathrm{C}$ in $1 \mathrm{~s}^{-1}$ and $1300{ }^{\circ} \mathrm{C}$ in $0.1 \mathrm{~s}^{-1}$ ), a remarkable variation 
between experimental and computed flow stress datas could be observed in Fig. 5a and c, respectively.

To further assess the prediction accuracy of the developed model, we introduced the average relative error (AARE):

$$
\operatorname{AARE}(\%)=\frac{1}{\mathrm{~N}} \sum_{\mathrm{i}}^{\mathrm{N}}\left|\frac{\sigma_{\mathrm{e}}^{\mathrm{i}}-\sigma_{\mathrm{p}}^{\mathrm{i}}}{\sigma_{\mathrm{e}}^{\mathrm{i}}}\right| \times 100 \%
$$

Where $\sigma_{\mathrm{e}}^{\mathrm{i}}$ is the experimental value, $\sigma_{\mathrm{p}}^{\mathrm{i}}$ is the predicted value, and $\mathrm{N}$ is the total number of data. The value of AARE is 3.6\%, which indicates a good prediction accuracy of the developed model.
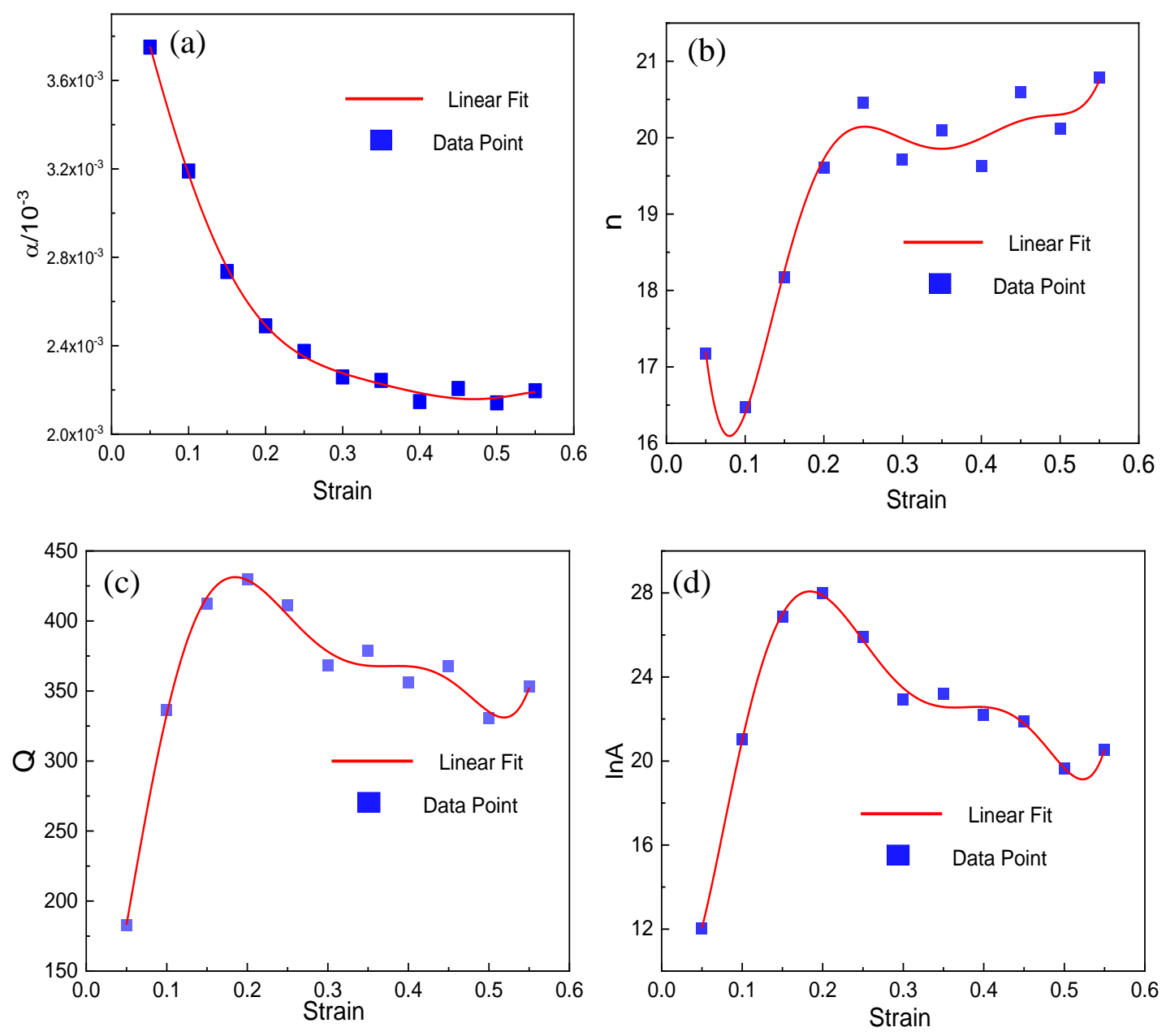

Fig. 11. Relationship between the strain and material constants: (a) a; (b) n; (c) Q; (d) $\ln \mathrm{A}$.

\section{Conclusions}

1. Extremely uniform nanosized $\mathrm{Zr}(\mathrm{Y}) \mathrm{O}_{2}$ particles strengthened tungsten alloys were 
fabricated through the hydrothermal method and mechanical alloying, followed by hot isostatic pressure.

2. The average particle size is about $410 \mathrm{~nm}$. Through TEM observation, lots of nanosized oxide particles less than $50 \mathrm{~nm}$ exists in the tungsten matrix.

3. The $\mathrm{W}-0.25 \mathrm{wt} \% \mathrm{Zr}(\mathrm{Y}) \mathrm{O}_{2}$ alloy possesses the highest ultimate compressive strength of $1577 \mathrm{MPa}$ and the fracture strain of 0.262 , which are approximately $25.2 \%$ and $40.5 \%$ higher than those of the pure tungsten, respectively. Moreover, the fabricated $\mathrm{W}-\mathrm{Zr}(\mathrm{Y}) \mathrm{O}_{2}$ alloys exhibit better microstructure and compressive properties compared to some published experimental results.

4. The relationship between flow stress, strain rate, and deformation temperature was investigated through establishing the constitutive equation and strain compensation model. The values o AARE is $3.6 \%$ respectively, which indicates that the developed constitutive equation could predict the flow stress with good correlation.

\section{Conflicts of interest}

There are no conflicts to declare.

Founding: This work is supported by National Natural Science Foundation of China [No. 51672070], National Natural Science Foundation of China [No. 51874185], Henan province science and technology innovation talent plan, China [No. 2017JQ0012] and Graduate Research and Innovation Projects in Jiangsu Province [ No. KYCX19_0182].

\section{Acknowledgements}

We would like to thank all the researchers who participated in our works discussed in the paper and whose names appear in references.

\section{References}

[1] G. A. Das, S. K. Rao, T. K. Nandy, Thermo-mechanical processing, microstructure and tensile properties of a tungsten heavy alloy, Mater. Sci. Eng. A. 613 (2014) 48-59.

[2] Q. Wei, L. J. Kecskes, Effect of low temperature rolling on the tensile behavior of 
commercially pure tungsten, Mater. Sci. Eng. A .491 (2008) 62-69.

[3] H. Bolt, V. Barabash, W. Krauss, J. Linke, R. Neu, S. Suzuki, N. Yoshida, A. U. Team, Materials for the plasma-facing components of fusion reactors, J. Nucl. Mater. 329 (2004) 66-73.

[4] Y. Kim, M. H. Hong, S. H. Lee, E. P. Kim, S. Lee, J. W. Noh, The effect of yttrium oxide on the sintering behavior and hardness of tungsten, Met. Mater. Int. 12 (3) (2006) 245-248.

[5] V. Barabash, M. Akiba, I. Mazul, M. Ulrickson, G. Vieider, Selection, Development and characterisation of plasma facing materials for ITER, J. Nucl. Mater. 233-237 (1996) 718-23.

[6] M. A. Yar, S. Wahlberg, H. Bergqvist, H. G. Salem, M. Johnsson, M. Muhammeda, Chemically produced nanostructured ODS-lanthanum oxide-tungsten composites sintered by spark plasma, J. Nucl. Mater. 408 (2011) 129-135.

[7] L. Veleva, R. Schaeublin, M. Battabyal, T. Plociski, N. Baluc, Investigation of microstructure and mechanical properties of $\mathrm{W}-\mathrm{Y}$ and $\mathrm{W}-\mathrm{Y}_{2} \mathrm{O}_{3}$ materials fabricated by powder metallurgy method, Int. J. Refract. Met. Hard Mater. 50 (2015) 210-216.

[8] R. Liu, Z. Xie, Q. Fang, T. Zhang, X. Wang, T. Hao, C. Liu, Y. Dai, Nanostructured yttria dispersion-strengthened tungsten synthesized by sol-gel method, J Alloy Compd. 657 (2016) 73-80.

[9] M. Samaras, P. M. Derlet, H. Van Swygenhoven, M. Victoria, Computer Simulation of Displacement Cascades in Nanocrystalline Ni, Phys. Rev. Lett. 88 (2002) 125505.

[10] R. Liu, X. P. Wang, T. Hao, C. S. Liu, Q. F. Fang, Characterization of ODS-tungsten microwave-sintered from sol-gel prepared nano-powders, J. Nucl. Mater. 450 (2014) 69-74.

[11] M. A. Yar, S. Wahlberg, H. Bergqvist, Spark plasma sintering of tungsten-yttrium oxide composites from chemically synthesized nanopowders and microstructural characterization, J. Nucl. Mater. 412 (2011) 227-232.

[12] M. A. Yar, S. Wahlberg, H. Bergqvist, Chemically produced nanostructured ODS-lanthanum oxide-tungsten composites sintered by spark plasma, J. Nucl. Mater. 
408 (2011) 129-135.

[13] Y. Shen, Z. Xu, K. Cui, J. Yu, Microstructure of a commercial W-1\% $\mathrm{La}_{2} \mathrm{O}_{3}$ alloy, J. Nucl. Mater. 455 (2014) 234-241.

[14] F. N. Xiao, L. J. Xu, Y. C. Zhou, K. M. Pan, J. W. Li, W. Liu, S. Z. Wei, Preparation, microstructure, and properties of tungsten alloys reinforced by $\mathrm{ZrO}_{2}$ particles, Int. J. Refract. Met. Hard Mater. 64 (2017) 40-46.

[15] S. Qu, S. Gao, Y. Yuan, C. Li, Y. Lian, X. Liu, W. Liu, Effects of high magnetic field on the melting behavior of $\mathrm{W}-1 \mathrm{wt} \% \mathrm{La} 2 \mathrm{O} 3$ under high heat flux, Journal of Nuclear Materials 463 (2015) 189-192.

[16] Z. Li, Y. B. Chen, S. Z. Wei, F. N Xiao, S. H. Siyal, L. J. Xu, Flow behavior and processing map for hot deformation of $\mathrm{W}-1.5 \mathrm{ZrO}_{2}$ alloy, J Alloy Compd. 802 (2019) 118-128.

[17] F. Xiao, L. Xu, Y. Zhou, K. Pan, J. Li, W. Liu, S. Wei, A hybrid microstructure design strategy achieving $\mathrm{W}-\mathrm{ZrO}_{2}(\mathrm{Y})$ alloy with high compressive strength and critical failure strain, J Alloy Compd. 708 (2017) 202-212.

[18] C. J. Wang, L. Q. Zhang, S. Z. Wei, K. M. Pan, X. C. Wu, Q. K. Li, Preparation, microstructure, and constitutive equation of W-0.25 wt $\% \mathrm{Al}_{2} \mathrm{O}_{3}$ alloy, Mater. Sci. Eng. A 744 (2019) 79-85.

[19] U. R. Kiran, M. P. Kumar, M. Sankaranarayana, K. Singh, T. K. Nandy, High energy milling on tungsten powders, Int. J. Refract. Met. Hard Mater. 48 (2015) 74-81.

[20] Y. Han, J. Fan, T. Liu, H. C. Cheng, J. M. Tian, The effects of ball-milling treatment on the densification behavior of ultra-fine tungsten powder, Int. J. Refract. Met. Hard Mater. 29 (2011) 743-750.

[21] H. Z. Li, M. Zeng, X. P. Liang, Flow behavior and processing map of PM Ti-47Al-2Cr-0.2Mo alloy, T. Nonferr. Metal. Soc. 22(4) (2012) 754-760.

[22] R. Liu, Y. Zhou, T. Hao, T. Zhang, X. P. Wang, C. S. Liu, Q. F. Fang, Microwave synthesis and properties of fine-grained oxides dispersion strengthened tungsten, $\mathrm{J}$. Nucl. Mater. 424 (2012) 171-175.

[23] H. Kurishita, S. Kobayashi, K. Nakai, T. Ogawa, A. Hasegawa, K. Abe, H. 
Arakawa, S. Matsuo, T. Takida, K. Takebe, M. Kawai, N. Yoshida, Development of ultra-fine grained $\mathrm{W}-(0.25-0.8) \mathrm{wt} \% \mathrm{TiC}$ and its superior resistance to neutron and 3 MeV He-ion irradiations, J. Nucl. Mater. 377 (2008) 34-40.

[24] H. Kurishita, Y. Amano, S. Kobayashi, K. Nakai, H. Arakawa, Y. Hiraoka, T. Takida, K. Takebe, H. Matsui, Development of ultra-fine grained W-TiC and their mechanical properties for fusion applications, J. Nucl. Mater. 367-370 (2007) 1453. [25] Z. M. Xie, R. Liu, T. Zhang, Q. F. Fang, C. S. Liu, X. Liu, G. N. Luo, Achieving high strength/ductility in bulk $\mathrm{W}-\mathrm{Zr}-\mathrm{Y} 2 \mathrm{O} 3$ alloy plate with hybrid microstructure, Mater. Design. 107 (2016) 144-152.

[26] W. J. Yu, Y. T. Zheng, Y. D. Yu, Precipitation mechanism and microstructural evolution of $\mathrm{Al}_{2} \mathrm{O}_{3} / \mathrm{ZrO}_{2}\left(\mathrm{CeO}_{2}\right)$ solid solution powders consolidated by spark plasma sintering, J Mater Sci Technol. 41 (2020) 149-158.

[27] C. J. Wang, L. Q. Zhang, S. Z. Wei, K. M. Pan, X. C. Wu, Q. K. Li, Effect of $\mathrm{ZrO}_{2}$ content on microstructure and mechanical properties of $\mathrm{W}$ alloys fabricated by spark plasma sintering, Int. J. Refract. Met. Hard Mater. 79 (2019) 79-89.

[28] C. J. Wang, L. Q, Zhan, S. Z. Wei, K. M. Pan, X. C. Wu, Q. K. Li, Microstructure and preparation of an ultra-fine-grained $\mathrm{W}-\mathrm{Al}_{2} \mathrm{O}_{3}$ composite via hydrothermal synthesis and spark plasma sintering, Int. J. Refract. Met. Hard Mater, 72 (2018) 149-156.

[29] Z. Li, L. J. Xu, S. Z. Wei, C. Chen, F. N. Xiao, Fabrication and mechanical properties of tungsten alloys reinforced with c-ZrO2 particles, J. Alloy. Comp. 769 (2018) (2018) 694-705.

[30] A. Muñoz, M. A. Monge, B. Savoini, M. E. Rabanal, G. Garces, R. Pareja, $\mathrm{La}_{2} \mathrm{O}_{3}$-reinforced $\mathrm{W}$ and $\mathrm{W}-\mathrm{V}$ alloys produced by hot isostatic pressing, J. Nucl. Mater. 417 (2011) 508-511.

[31] M. Y. Zhao, Z. J. Zhou M. Zhong, J. Tan, Y. Y. Lian, X. Liu, Thermal shock behavior of fine grained $\mathrm{W}-\mathrm{Y}_{2} \mathrm{O}_{3}$ materials fabricated via two different manufacturing technologies, J. Nucl. Mater. 470 (2016) 236-243.

[32] R. Liu, Z. M. Xie, T. Zhang, Q. F. Fang, X. P. Wang, T. Hao, C. S . Liu, Y. Dai, Mechanical properties and microstructures of $\mathrm{W}-1 \% \mathrm{Y}_{2} \mathrm{O}_{3}$ microalloyed with $\mathrm{Zr}$, Mater. 
Sci. Eng. A 660 (2016) 19-23.

[33] M. V. Aguirre, A. Martín, J. Y. Pastor, J. L. Lorca, M. A. Monge, R. Pareja, Mechanical properties of $\mathrm{Y}_{2} \mathrm{O}_{3}$-doped W-Ti alloys, J. Nucl. Mater. 404 (2010) 203-209.

[34] Y. M. Ki, K. H. Lee, E. P. Kim, D. I. Cheong, S. H. Hong, Fabrication of high temperature oxides dispersion strengthened tungsten composites by spark plasma sintering process, Int. J. Refract. Met. Hard Mater. 27 (2009) 842-846.

[35] I. Wesemann, W. Spielmann, P. Heel, A. Hoffmann,Fracture strength and microstructure of ODS tungsten alloys, Int. J. Refract. Met. Hard Mater. 28 (2010) 687-691.

[36] N. Liu, Z. Dong, Z. Q. Ma, L. M. Yu, C. Li, C. X. Liu, Q. Y. Guo, Y. C. Liu, Eliminating bimodal structures of $\mathrm{W}-\mathrm{Y}_{2} \mathrm{O}_{3}$ composite nanopowders synthesized by wet chemical method via controlling reaction conditions, J. Alloy. Comp. 774 (2019) $122-128$

[37] Z. Dong, N. Liu, Z. Q. Ma, C. X. Liu, Q. Y. Guo, Y. C. Liu, Preparation of ultra-fine grain $\mathrm{W}-\mathrm{Y}_{2} \mathrm{O}_{3}$, alloy by an improved wet chemical method and two-step spark plasma sintering, J. Alloy. Comp. 695 (2017) 2969-2973.

[38] C. P. Cui, Y. M. Gao, S. Z. Wei, G. S. Zhang, Y. C. Zhou, X. W. Zhu, Microstructure and high temperature deformation behavior of the $\mathrm{Mo}^{-\mathrm{ZrO}_{2}}$ alloys, $\mathrm{J}$. Alloys Compd. 716 (2017) 321-329.

[39] F. N. Xiao, Q. Miao, S. Z. Wei, Z. Li, T. L. Sun, L. J. Xu, Microstructure and mechanical properties of $\mathrm{W}-\mathrm{ZrO}_{2}$ alloys by different preparation techniques, $\mathrm{J}$ Alloys Compd, 774 (2019): 210-221.

[40] L. J. Xu , S. Z. Wei , Q. Liu , G. S. Zhang, J. W. Li, Microstructure and high-temperature frictional Wear property of Mo-based composites reinforced by aluminum and lanthanum oxides, Tribol. T, 56.5 (2013) 833-840.

[41] Y. C. Lin, X. M. Chen, A critical review of experimental results and constitutive descriptions for metals and alloys in hot working, Mater. Des. 32 (4) (2011) 1733-1759.

[42] A. He, G. L. Xie, X. Y. Yang, X. T. Wang, H. L. Zhang, A physically-based 
constitutive model for a nitrogen alloyed ultralow carbon stainless steel, Comput. Mater. Sci. 98 (2015) 64-69.

[43] Y. Zhang, H. L. Sun, A .A. Volinsky, et al., Hot workability and constitutive model of the Cu-Zr-Nd alloy, Vacuum 146 (2017) 35-43.

[44] J. Wang, G. Q. Zhao, L. Chen, J. L. Li, A comparative study of several constitutive models for powder metallurgy tungsten at elevated temperature, Mater. Des. 90 (2016) 91-100.

[45] A. Galiyev, R. Kaibyshev, G. Gottstein, Correlation of plastic deformation and dynamic recrystallization in magnesium alloy ZK60, Acta Mater. 49 (7) (2011) 1199-1207.

[46] W. Setyawan, R.J. Kurtz, Effects of transition metals on the grain boundary cohesion in tungsten, Scripta Mater. 66 (2012) 558-561.

[47] J. Cai, F.G. Li, T.Y. Liu, et al., Constitutive equations for elevated temperature flow stress of Tie6Ale4V alloy considering the effect of strain, Mater. Sci. Eng. A 32 (3) (2011) 1144-1151.

[48] W. R. Lu, C. Y. Gao, Y. L. Ke, Constitutive modeling of two-phase metallic composites with application to tungsten-based composite $93 \mathrm{~W}-4.9 \mathrm{Ni}-2.1 \mathrm{Fe}$, Mater. Sci. Eng. A 592 (2014) 136-142.

[49] Q. G. Meng, C. G. Bai, D. S. Xu, Flow behavior and processing map for hot deformation of ati 425 titanium alloy, J. Mater. Sci. Technol. 34 (04) (2018) 105-114. [50] T. Dummer, J. C. Lasalvia, G. Ravichndran, G. Ravichandran, M. A. Meyers, Effect of strain rate on plastic flow and failure in polycrystalline tungsten, Acta Mater. 46 (17) (1998) 6267-6290. 
Graphical Abstract (for review)
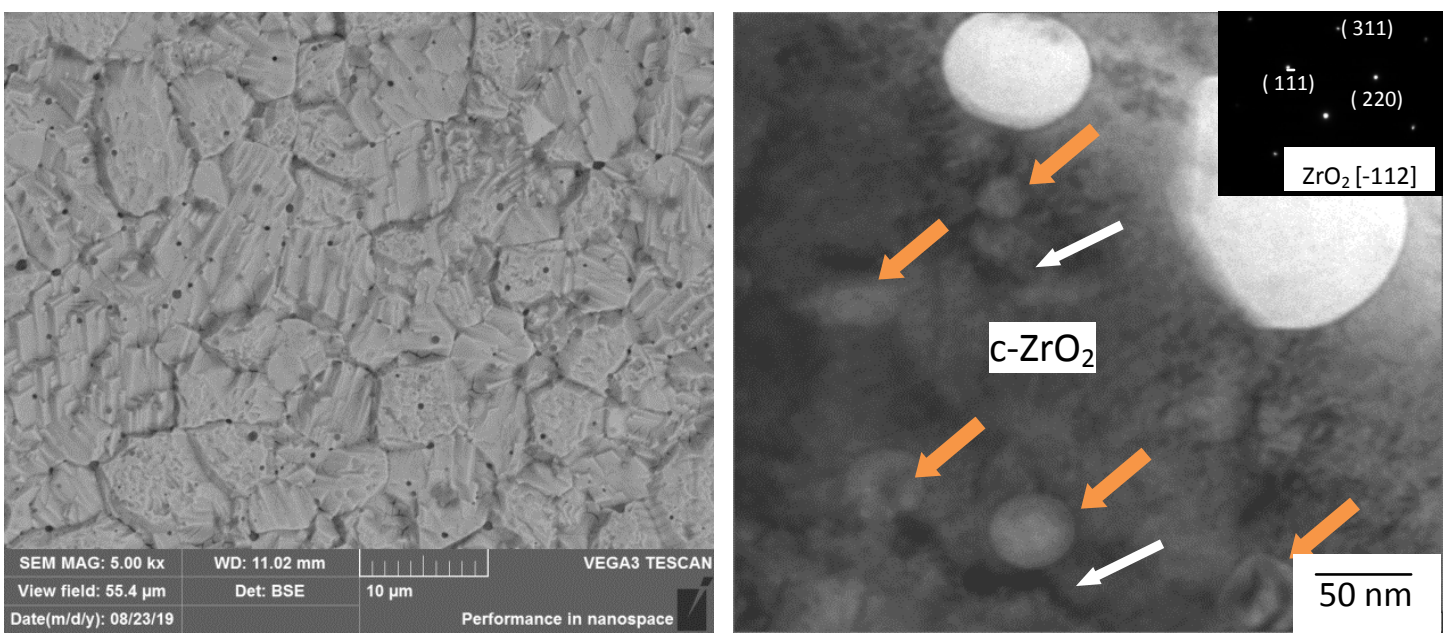

$\mathrm{ZrO}_{2}[-112]$
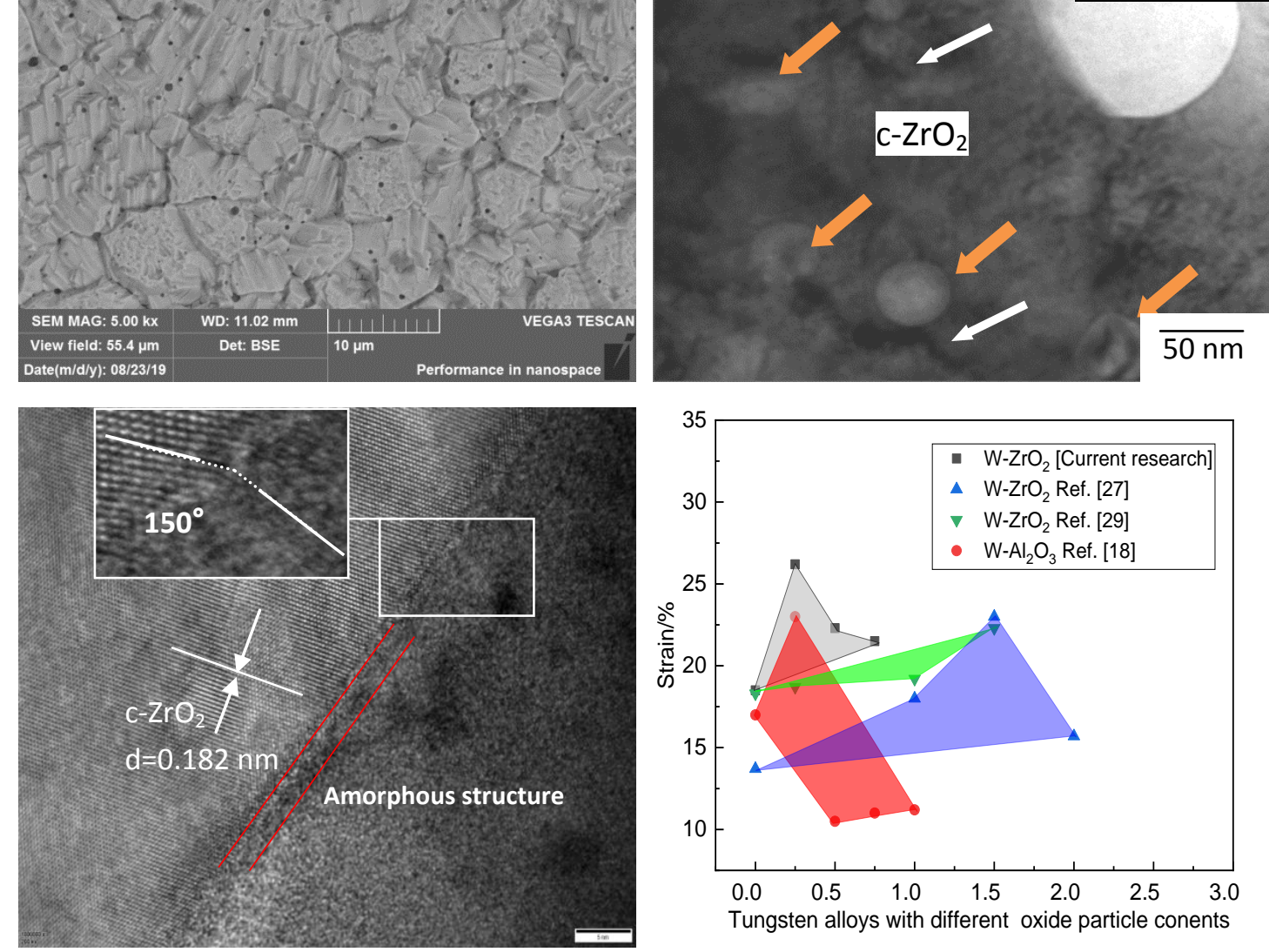

$\overline{50 \mathrm{~nm}}$

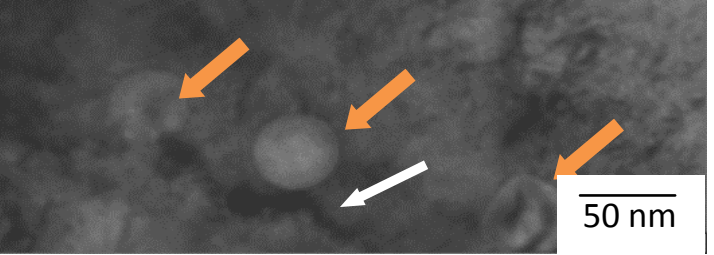




\section{Highlights}

Extremely uniform nanosized $\mathrm{Zr}(\mathrm{Y}) \mathrm{O}_{2}$ dispersion-strengthened $\mathrm{W}$ alloys were prepared;

More than $90 \%$ of particles have diameters in the range of $100 \sim 650 \mathrm{~nm}$;

$\mathrm{Zr}(\mathrm{Y}) \mathrm{O}_{2}$ particles exhibit a good bonding with the tungsten phase;

Compressive strength and strain reach to $1577 \mathrm{MPa}$ and 0.262 , respectively. 


\section{Credit Author Statement}

Liujie Xu and Shizhong Wei: Methodolgy; Qiang Miao and Shizhong Wei: Analysis; Fangnao Xiao and Shiwei Zuo: Experiments, Writing-Original draft preparation; Thierry Barriere and Gang Cheng: Investigation, Writing-Reviewing and Editing. All authors : Discussions. 
${ }^{\star}$ Declaration of Interest Statement

\section{Declaration of interests}

The authors declare that they have no known competing financial interests or personal relationships that could have appeared to influence the work reported in this paper. 